\title{
FINANCIEROS JUDÍOS \\ EN LA PRIMERA ÉPOCA DE LA REPOBLACIÓN \\ DEL REINO DE SEVILLA: \\ LA CRISIS DEL REALENGO EN EL CONCEJO DE NIEBLA
}

$(1262-1368)$

MANUEL GONZÁLEZ JIMÉNEZ

Universidad de Sevilla

ISABEL MONTES ROMERO-CAMACHO

Universidad de Sevilla

\section{SUMARIO}

1. Introducción.- 2. Alfonso X (1252-1284) y la conquista y repoblación del antiguo reino de Niebla.- 3. Sancho IV (1284-1295) y el comienzo de las dificultades.- 4. Fernando IV (1295-1312) y la difícil resistencia.- 5. Alfonso XI (1312-1350) y el principio del fin de Niebla como concejo de realengo.- Apéndice documental.

\section{INTRODUCCIÓN}

Mucho se ha hablado del importante papel desempeñado por los judíos a lo largo de todo el proceso repoblador de Andalucía y, más concretamente, del reino de Sevilla, por lo que pueden llegar a ser incluso innumerables los datos aportados por los mejores especialistas, tanto sobre 
la historia de los judíos en la España cristiana', como en todo lo relativo a la repoblación de Andalucía ${ }^{2}$. Por otra parte, la relación entre una y otra premisa, es decir, el protagonismo de los judíos en la repoblación del reino de Sevilla, ha tratado de establecerse, más concretamente, en algunos trabajos de síntesis ${ }^{3}$. Sea como fuere, todo parece indicar que esta realidad no sólo sirvió para definir algunos rasgos característicos de la nueva sociedad, nacida de la conquista cristiana, sino que marcó, de forma indeleble, el futuro devenir histórico de Andalucía $^{4}$.

Sin embargo, a pesar de todas estas contribuciones, todavía, que sepamos, no se ha llevado a cabo una investigación, sistemática y pormenorizada, de este hecho a nivel local, que pudiera servir para constatar y, a la vez, reafirmar, las ideas de carácter general. Afortunadamente, contamos con un ejemplo bastante ilustrativo en el antiguo reino taifa de Niebla, incorporado a la corona de Castilla en 1262, tras haber sido conquistado por Alfonso X.

Es cierto que su devenir histórico, durante la baja Edad Media, nos es bien conocido, gracias a la extraordinaria y casi definitiva aportación realizada por el prof. Miguel Ángel Ladero Quesada, en su magnífico

\footnotetext{
'Entre los muchos investigadores que se han ocupado del tema, podemos citar a José AMADOR DE LOS RIOS, Historia social, politica y religiosa de los judios de España y Porrugal, Madrid, 1973.- Yitzhak BAER. Historia de los judios en la España cristiana. vol. I. Madrid. 1981 ... así como a uno de los primeros historiadores de los judíos sevillanos: F.M. MONTERO DE EsPinosa. Relación histórica de la judería de Sevilla. Sevilla. 1849

'Afortunadamente, contamos con una documentación excepcional sobre este proceso. estudiada para el ámbito geohistórico que nos concierne. entre otros, por don Julio GonZález, en su extraordinaria aportación sobre el Repartimiento de Sevilla, 2 vols. Sevilla, 1998. así como por Manuel GONZÁLEZ JIMÉNEZ y Antonio GONZÁLEZ GÓMEZ, Repartimiento de Jeré:Cádiz, 1980.- Una interpretación de todo el proceso repoblador andaluz en Manuel GonzÁLEz JIMÉNEZ, En torno a los orígenes de Andalucia, $2^{\text {a }}$ ed., Sevilla, 1988

${ }^{3}$ Isabel MONTES ROMERO-CAMACHO, Notas para el estudio de la juderia sevillana en la baja Edad Media (1248-1391), en "Historia. Instituciones. Documentos", 10 (1982), pp. 251-277: El antijudaísmo o antisemitismo sevillano hacia la minoría hebrea, en "Segundos Encuentros Judaícos de Tudela". 1996. pp. 73-157: Moros y judios en Carmona. Vida y tragedia de unas minorias. en "Actas del I Congreso de Historia de Carmona. Edad Media". Sevilla. 1998. pp. 499-538: Mudéjares y judios en la Sevilla del siglo XIII. en "Sevillla 1248. Congreso" Internacional conmemorativo del 750 Aniversario de la conquista de Sevilla por Fernando III". Sevilla, noviembre 1998 (en prensa)

${ }^{4}$ Manuel GonZález JimÉnEZ, En torno a los origeness de Andalucía. 2a ed.. Sevilla. 1988.Diplomatario andaluz de Alfonso $X$ el Sabio, Sevilla, 1991.- Alfonso $X$ y las minorias confesionales de mudéjares y judios, en "Alfonso X. Aportaciones de un rey castellano a la construcción de Europa", Murcia, 1997, pp. 73-90.- El fracaso de la comvivencia de moros y. judios en Andalucía (ss. XIII-XV), en "Proyección histórica de España en sus tres culturas: Castilla y León, América y el Mediterráneo" ". Junta de Castilla y León, 1993, pp. 129-149...
} 
discurso de ingreso en la Real Academia de la Historia ${ }^{5}$. Por ello, en las páginas que siguen, sólo trataremos de analizar, en un caso concreto, cuáles fueron algunas de las circunstancias, estructurales y coyunturales, que afectaron a la Andalucía cristiana durante el primer siglo de la repoblación. que puede considerarse como el de su nacimiento, y que, en lo que hace a Niebla, fue el de su era realenga (1262-1368), por lo que trataremos de plantearnos en qué medida estas circunstancias, muchas veces negativas, precipitaron su definitiva entrada en señorío, gracias a la merced otorgada por el nuevo monarca castellano, Enrique II de Trastámara, el uno de mayo de 1368, a don Juan Alonso de Guzmán, cabeza del más importante linaje sevillano, quien recibió, además del señorío sobre Niebla y su extenso territorio, el título de conde, dando comienzo a su era señorial (1368$1516)^{7}$.

Así pues, este complejo proceso, que se prolongó durante los reinados de Alfonso X (1252-1284), Sancho IV (1284-1295), Fernando IV (1295-1312), Alfonso XI (1312-1350) y Pedro I (1350-1368), trataremos de observarlo tomando como hilo conductor el papel desempeñado por los financieros judíos que actuaron en él, muchas veces como protagonistas, tanto los que formaban parte de la aljama de Niebla, como los que pertenecían a otras importantes comunidades judías castellanas, como era el caso de la sevillana o la de Toledo, y que, en numerosas ocasiones, actuaban al servicio directo de la corona de Castilla.

\section{ALFONSO X (1252-1284) \\ Y LA CONQUISTA Y REPOBLACIÓN \\ DEL ANTIGUO REINO DE NIEBLA}

Como hemos dicho, todo este primer periodo de la historia del antiguo reino de Niebla está muy bien estudiado, tanto gracias a la riqueza de las fuentes que se nos han conservado, como al interés de los estudiosos acerca de él. Por tanto, sólo nos limitaremos a recordar ạlgunas de las fechas

\footnotetext{
${ }^{5}$ Miguel Ángel LADERo QUESADA. Niebla, de reino a condado. Noticias sobre el Algarbe andaluz en la Baja Edad Media. Discurso de ingreso en la Real Academia de la Historia. Madrid. 1992

'Miguel Ángel Ladero Quesada. Niebla, de reino a condado, cit., pp. 19-60

${ }^{7}$ Miguel Ángel LADERo QueSADA. Niebla, de reino a condado. cit., pp. 61-101
} 
referenciales de su etapa de nacimiento, en la que destaca, además de su completa inserción en el proceso repoblador del reino de Sevilla, la estrecha vinculación del concejo realengo de Niebla con el concejo hispalense, ya que, aparte de depender de él jurisdiccionalmente, fue organizado según su modelo.

De esta manera, en 1262, Alfonso X, tras haber ofrecido una generosa capitulación a su rey Abén Mahfot, ocupó el antiguo reino de Niebla, que era, sin duda, una pieza clave para poder cumplir sus pretensiones sobre el Algarbe.

En febrero de 1263, el Rey Sabio concedió carta puebla a Niebla, donde, además de las mismas franquezas y privilegios que a los de Sevilla, otorgó a sus vecinos el Fuero Real que, al final del reinado de Alfonso X, sería reemplazado por el Fuero de Sevilla.

A partir de entonces, son numerosas las noticias que nos demuestran el empeño de don Alfonso por favorecer la repoblación de Niebla, aunque, por desgracia, no se nos ha conservado ni su libro de repartimiento, ni otros datos directos, como padrones, relativos a tan importante proceso. En relación a él, sólo estamos en condiciones de afirmar que, en una fecha tan temprana como el día de San Juan de 1263, en que tuvo lugar un alarde de los vecinos de Niebla, ya estaba muy bien poblada, así como que, al parecer, la mayor parte de su población mudéjar emigró, tras la revuelta de 1264 .

Sea como fuere, en abril de 1267, el repartimiento de Niebla ya se había dado por terminado, tras haberse llevado a cabo el amojonamiento de su término, que seguía siendo el mismo que en tiempos de moros, una vez segregados los de Huelva y Gibraleón, reconocidas ahora como villas independientes.

A partir de entonces, la vida económica de los habitantes de Niebla estaba centrada, especialmente, en el pastoreo, la explotación de los montes y el comercio, sector en el que se le abrían magníficas posibilidades de futuro, dada su extraordinaria posición, como extremo occidental del reino de Sevilla, entre los ríos Tinto y Odiel, separada del vecino reino de Portugal por el Guadiana y volcada al Oceáno Atlántico.

Sería en torno a 1280 cuando parece estar terminada la primera repoblación y organización -en los planos civil y eclesiástico- de Niebla, aunque no por ello el Rey Sabio dejó de hacerla objeto de sus desvelos, según podemos ver por la confirmación, en abril de 1282, de los privilegios de Niebla, Huelva y Gibraleón, así como por la orden dada a Sevilla, en 
julio de 1283 , de que enviase traslado a Niebla de todos sus privilegios, franquicias y libertades.

Pero este interés que, desde su conquista, don Alfonso había demostrado por el territorio del antiguo reino taifa de Niebla, no fue obstáculo para que, en marzo de 1283 , decidiera conceder, vitaliciamente, el señorío de Niebla, Huelva y Gibraleón a su hija doña Beatriz, viuda de Alfonso III de Portugal. Es cierto que esta cesión nunca se llevó a efecto, pero, aunque sólo fuese en teoría, la condición realenga del Algarbe andaluz ya había sufrido su primera amenaza, algo que, andando el tiempo, habría de transformarse en una dinámica imparable que culminaría con su definitiva señorialización ${ }^{8}$.

\section{SANCHO IV (1284-1295) \\ Y EL COMIENZO DE LAS DIFICULTADES}

El breve reinado de Sancho IV (1284-1295) supuso para Niebla la prosecución de la línea política emprendida por su padre ${ }^{9}$. Así, mientras que por una parte se va consolidando como un concejo realengo ${ }^{10}$, organizado

\footnotetext{
${ }^{8}$ Todos estos acontecimientos, mucho más pormenorizados, en Manuel GoNZÁLEZ JIMÉNEZ, Diplomatario andaluz de Alfonso X el Sabio, cit., pp. LXXVIII-LXXX, Alfonso X el Sabio, 1252-1284, en "Corona de España, Reyes de Castilla y León", II, Palencia, 1993, pp. 169-170 y también en su nueva aportación Huelva, tierra de frontera, en "Huelva en la Edad Media. Reflexiones, aportaciones y nuevas perspectivas veinte años después", Universidad de Huelva, 1999, pp. 15-35, así como, sobre todo, en Miguel Ángel LADERO QUESADA, Niebla, de reino a condado, cit., pp. 19-25.- La documentación sobre Niebla de época alfonsí ha sido editada

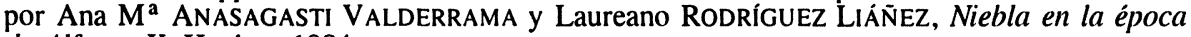
de Alfonso X, Huelva, 1984.

${ }^{9}$ Todo lo relativo al reinado de Sancho IV en el clásico libro de Mercedes GAIBROIS DE BALLESTEROS, Historia del reinado de Sancho IV de Castilla, 3 vols., Madrid, 1922-1928, así como en el más reciente de José Manuel NiETo SorIA, Sancho IV. 1284-1295, en "Corona de España", III, Palencia, 1994.

${ }^{10}$ Archivo Histórico Nacional (en adelante: AHN), Diversos. Concejos y ciudades, leg. 75, n. $6^{\prime}$ (Documento I del Apéndice), en 1294, don Juan Fernández, Adelantado Mayor de la Frontera, se dirige a los "alcaldes del rey en Niebla", dándoles órdenes para resolver la querella presentada por los "omes buenos del conceio de Niebla" acerca del logro de los judíos.- Noticias sobre la evolución del régimen local en Niebla, Huelva y Gibraleón, durante el período histórico que nos interesa (1262-1368) en Miguel Angel LADERo QUESADA, Niebla, de reino a condado, cit., pp. 58-60.
} 
en todo según el modelo de Sévilla", por otra aparece completamente integrada en la corona de Castilla, al tomar parte en sus actividades, tanto políticas, como fiscales que, en una tierra de frontera, como era Andalucía, estaban dirigidas, principalmente, a la lucha contra los musulmanes.

En este sentido. Sancho IV heredó no sólo los problemas financieros de su padre, sino también su necesidad de obtener recursos, utilizados ahora, especialmente, para detener la invasión meriní y continuar la guerra fronteriza ${ }^{12}$. Así, tenemos noticias de que en su primer año de reinado, entre 1284-1285, lós leales súbditos castellános hubieron de hacer frente al pago de dos monedas foreras: una ordenada cobrar por el Rey Sabio en 1284, con objeto de reprimir la sublevación del infarte don Juan y la otra recaudada, como era tradicional, a la subida al trono del nuevo monarca. También en 1285, solicitó al reino, en Burgos y en Sevilla, dos servicios de Cortes, destinados a contener a los benimerines y a la guerra en la Frontera. En 1288, las Cortes de Haro concedieron a Sancho IV un servicio anual, durante diez años. de los cuales. los cinco primeros se recaudaron entre 1288 y 1292, mientras que el sexto, en 1293. se destinó a los gastos del cerco de Tarifa y el séptimo y octavo fueron pagados en $1294^{13}$.

Nuevamente, con Sancho IV, el principal cargo financiero del reino, el de almojarife o tesorero mayor volvía a estar ocupado por un judío: don Abrahem el Barchilón, con lo que se continuaba la tradición de los reyes de Castilla, interrumpida por Alfonso X, en 1280, con la ejecución del infortunado don Çag de la Maleha ${ }^{14}$.

\footnotetext{
"El 18 de noviembre de 1285. en Sevilla. Sancho IV confirmaba el privilegio otorgado a Niebla. por Alfonso X, en 1263, donde le concedia el mismo status jurídico del concejo de Sevilla (Archivo de los Duques de Medina Sidonia (en adelante: ADMS). Legs. 345. 740 y 756.- Miguel Ángel LADERo QueSADA. Niebla, de reino a conclado, cit., p. 26, n. 22).- Años. más tarde. ante la constatación de que los privilegios. francuicias y libertades concedidos por los reyes al concejo hispalense habian sufrido algunas modificaciones y ampliaciones. el concejo de Niebla solicitó del sevillano. el 2 de julio de 1293. a través de su mayordomo y de su personero, que le enviase una nueva copia (ADMS. Legs. 345 y 740.- Miguel Ángel L.ADERO QUESADA. Niebla, de reino a condado. cit.. p. 26. n. 23).

'Los datos que siguen a continuación sobre la fiscalidad regia en tiempos de Sancho IV en Miguel Ángel LADERO QuisadA. Fiscalidad y poder real en Castilla (1252-1369). Madrid. 1993. pp. 63-64.

"Cortes de los antiguos reinos de León y de Castilla, Madrid. 1861-1903. I. pp. 99-106.

"José AMADOR DE los Rios. Historia social, politica y religiosa de los judios de España y. Portugal, cit. pp. 297-298. - Yitzhak BAER. Historia de los judios en la Esponara cristiana. cit. vol. I. pp. 100-104.- Joseph. F. O'Callaghan. El Rey Sabio. El reinado de Alfomson $X$ de Castillar. Sevillar. 1996, pp. 284-298.- Manuel GonzÁlez JimÉnEZ. Alfonso X el Salbio. 12521284. cit.. pp. 125-131 y Alfonso $X$ y las minorias confesionales de mudéjares y juclios, cit. pp.
} 
Una y otra realidades pueden observarse, con perfecta nitidez, en Niebla. Así, todavía en 1290, el concejo no había podido cumplir el pago de su parte correspondiente en los servicios de Cortes otorgados en 1284-1285: "la moneda postrimera que dieron al rey don Alfonso y la moneda primera" del reinado de Sancho IV, por lo que, el 24 de enero de 1290, se comprometió a hacerlo a don Zag Abenomarache, recibidor de las cuentas por el rey, y a don Abrahem el Barchilón ${ }^{15}$. De la misma forma, tenemos noticias de la contribución de la aljama judía de Niebla en la capitación exigida, en 1290 , a todas las juderías castellanas, cuya cuantía y reparto fue determinada por los repartidores judíos diputados por las distintas juderías de Castilla, reunidos en Huete, entre los que se encontraban los partidores de la Frontera. No sabemos la cantidad concreta aportada por Niebla, pues sólo se recoge la cifra pagada por Andalucía en su conjunto: 191.898 maravedíes, aunque se nos ha conservado el nombre del partidor que representó a los judíos de Niebla: don Jacob Yahion o Aben Yahia ${ }^{16}$.

De la misma forma, sabemos que la contribución de Niebla al almojarifazgo real, en 1294, fue de 17.250 maravedies $^{17}$, mientras que ese mismo año, su judería pagó a la corona 7.000 maravedíes, lo que nos habla

77-78. - Miguel Ángel LADERO QUESADA. Fiscalidad y poder real en Castilla (1252-1369). cit.. pp. 235-236. a la muerte de don Çag de la Maleha. Alfonso X nombró tesorero real a su hijo natural. don Alfonso Fernández: que actuaba también como mayordomo y que habia sido uno de los partidores de Niebla (Miguel Angel L.ADERO QUESADA. Niebla, de reino a comededo. cit. pp. 19-25).

15ADMS. Leg. 345.- Miguel Ángel LADERO QUESADA. Niebla, de reino a condado. cit. p. 30. nota 40.

"El denominado "padrón de Huete" ha sido publicado y estudiado, entre otros, por José AMADOR DE LOS RIOS. Historia social, política y religiosa de los judios de España y Porrugal. cit., pp. 298-303 y 916-931.- Fritz BAER. Die juden im christlichen Spanien: Urkunden und Regesten. Band II: Kastilien IInquisitionakten. Berlin. 1936 (repr. Westmead-Farnborough. 1970), doc. 96, pp. 81-88.- Carlos CARrete PARRondo. El repartimiento de Huete de 1290. "Sefarad". XXXVI (1976), pp. 121-140. - Francisco HERNÁNDEZ SÁNCHEZ, Sociedad y fisco enl el reino de Castilla durante el siglo XIII. Los textos fiscales de 1290-1292, Madrid. 1992. Iomo I pp. CXXXIII-CXLIV.- Miguel Ángel LADERO QUESADA. Fiscalidad y poder real en Castilla (1252-1369), cit., pp. 79-84.

${ }^{17}$ Cantidad digna de tener en cuenta si pensamos que la de Jerez fue de 22.500 maravedies. aunque ambas no son comparables con los 450.000 maravedies pagados por Sevilla (Según la Cuenta de la Frontera rendida, en 1294. por Juan Mathe de Luna, publicada por Mercedes Gaibrois Riaño, Historia de Sancho IV de Castilla. Madrid. 1922-1928, III. p. 583.- Miguel Ángel LADERO QUESADA. Fiscalidad y' poder real en Castilla (1252-1369). cit.. p. 151). 
de su importancia ${ }^{18}$. No obstante, también tenemos noticias de las dificultades atravesadas por los arrendadores judíos para terminar de cobrar el almojarifazgo de Niebla, en 1294, del que restaban por recaudar la pequeña cantidad de 1.150 maravedíes, y, sobre todo, el pecho de sus judíos, de ese mismo año, pues todavía no se habían pagado, nada menos, que 6.000 maravedíes $^{19}$.

Que las cosas estaban mal para los vecinos de Niebla, tanto cristianos como judíos, parece deducirse, en fin, de la carta enviada, el 1 de febrero de 1294, desde Tejada, por don Johan Fernández, Adelantado Mayor de la Frontera ${ }^{20}$, a los alcaldes del rey en Niebla, como respuesta a la querella presentada por los "omes buenos del conceio de Niebla"21. En ella se quejaban del interés excesivo que los prestamistas judíos pretendían cobrar a los vecinos de Niebla, superior al tres por quatro (33.3\%), a pesar de lo ordenado por Sancho IV, "... segunt dise la carta del rey que el consejo de

${ }^{18} \mathrm{La}$ de Jerez, al igual que la de Écija, sólo fue de 5.000 maravedíes, por lo que la aljama judía de Niebla sólo parece que fuera menor, por lo que hace a la Andalucía occidental, que las muy superiores de Córdoba, que pagó 38.333 maravedíes, y desde luego, Sevilla, la mayor de Andalucía y segunda de Castilla, después de Toledo, cuya contribución fue de 115.333 maravedíes (Según la Cuenta de la Frontera rendida, en 1294, por Juan Mathe de Luna, publicada por Mercedes GaIBRoIS Riaño, Historia de Sancho IV de Castilla, cit., III, p. 583.Miguel Ángel LADERO QUESADA, Fiscalidad y poder real en Castilla (1252-1369), cit., p. 84).

${ }^{19}$ Fritz BAER, Die juden im christlichen Spanien, cit., doc. 98, pp. 88-94: 1293-1294: "Libro de cuentas de la cancillería de Sancho IV, con los extractos siguientes que afectan a los judíos: Esto es lo que fico en los arrendadores de las rentas... En Benjamin e en Abrahem, su companero, del almoxarifadgo de Niebla, e an descuento por el vedamento de Portugal... 1.150 mrs.".- Las relaciones fronterizas entre Portugal y el reino de Sevilla, durante el reinado de Sancho IV, en Florentino PÉREZ EMBID, La frontera entre los reinos de Sevilla y Portugal, Sevilla, 1975, pp. 72-76.

${ }^{20}$ Rogelio PÉREZ BUSTAMANTE, El gobierno y la administración de los reinos de la corona de Castilla (1230-1474), II, Madrid, 1976, p. 301, es muy posible que sea don Juan Fernández, que ostentó el cargo de Adelantado Mayor de la Frontera entre 1293-1295.- Diego ORTIZ DE ZúÑIGA, Anales de Sevilla, cit., 2, año, 1396, cap. 5, p. 256, en 1295 era Adelantado Mayor de la Frontera don Juan Fernández, hijo de don Alfonso Fernández el Niño, hijo, a su vez, de Alfonso X (Noticias sobre don Alfonso Fernández el Niño, partidor de Niebla, Huelva y Jerez, señor de Molina y Mesa, alcaide del alcázar de Sevilla, adelantado mayor de Andalucía, entre otros, en Diego ORTIZ DE ZúNiıa, Anales de Sevilla, cit., 1, pp. 261, 282, 293, 296, 297, 340.- Julio GONZÁLEZ, Repartimiento de Sevilla, cit., I, pp. 80, 81, 88, 90 y II, p. 353.Manuel GonZÁlez JimÉnEZ, Diplomatario andaluz de Alfonso $X$, cit., ver la voz Alfonso Fernández, hijo de Alfonso $X$ en el índice, p. 660 , donde se señalan las páginas donde se contienen numerosas noticias sobre el personaje y Alfonso X el Sabio. 1252-1284, cit., pp. 21, $114,116,120,170,230,289,296)$.

${ }^{21}$ Documento I del Apéndice: AHN, Diversos. Concejos y ciudades, leg. 75, n. 6'.- CIT. Miguel Ángel LADERo QUESADA, Niebla, de reino a condado, cit., p. 29, nota 37, según una copia existente en el Archivo de los Duques de Medina Sidonia (ADMS), Leg. 345. 
Sevilla tiene sobre esta rasón"22. Igualmente, es importante destacar que el documento se refiere a los préstamos concedidos por los judíos a los vecinos de Niebla "del prostremero día de mayo primero que pasó acá" (el 31 de mayo de 1293), por lo que parece deducirse que la causa eficiente de su endeudamiento pudo ser la obligación de contribuir en el servicio de 1293, el sexto de los diez otorgados a Sancho IV por las Cortes de Haro de 1288, que estaba destinado a sufragar los gastos del asedio de Tarifa ${ }^{23}$.

Sea como fuere, el concejo de Niebla achacaba las malas condiciones económicas, en que se encontraban algunos de sus vecinos, a que se vieron obligados a pedir prestado dinero a los judíos "... y que el logro que dellos tienen es muy grant, en guisa que resciben gran danpno por que se podía tomar la villa...".

¿Pero, era tan grave, realmente, la situación?. Como sabemos, es verdad que los últimos años del reinado de Sancho IV fueron especialmente duros, aunque, desde luego, como hemos dicho, la crisis económica se dejó sentir en Niebla, tanto para los cristianos como para su aljama judía, cuya posición económica se deterioró, entre otras cosas, por las dificultades del

\footnotetext{
${ }^{22}$ Así pues, en este aspecto, como en otros muchos, Sancho IV no hizo sino continuar la trayectoria marcada por su padre, por ejemplo, en las Cortes de Valladolid de 1293, el 20 de mayo de 1293 (Cortes, I, pp. 114, 115 y 127.- Fritz BAER, Die juden im christlichen Spanien, cit., doc. 100, pp. 94-96). La regulación de la usura, con la fijación del interés en un tres por cuatro $(33.3 \%)$ ya había sido llevada a cabo por Alfonso $\mathrm{X}$, por ejemplo, en las Cortes de Valladolid de 1258, según consta en el Ordenamiento de Valladolid del 16 de enero de 1258 (Cortes, I, pp. 59-60.- Fritz BAER, Die juden im christlichen Spanien, cit., doc. 72, p. 56), algo que se mantuvo a lo largo de todo su reinado, con algunas excepciones, como cuando en las Cortes de Jerez de 1268 se aumentó el interés a un quatro por cinco $(25 \%)$, según aparece en la copia de sus cuadernos, realizada en Sevilla, el 30 de julio de 1268 (Cortes, I, pp. 68, 77, 80 ss.- Fritz BAER, Die juden im christlichen Spanien, cit., doc. 78, pp. 60-61), aunque, muy pronto, volvió a rebajarse a un $33.3 \%$, lo que sería habitual no sólo en Castilla, sino en la mayor parte de los reinos cristianos durante la baja Edad Media, siguiendo las directrices del IV Concilio de Letrán de 1215 (David ROMANO, Marco jurídico de la minoría judía en la corona de Castilla de 1214 a 1350, "Actas del II Congreso Internacional Encuentro de las Tres Culturas". Toledo, 1985, pp. 271-272 y Alfonso X y los judíos. Problemática y propuestas de trabajo, "Anuario de Estudios Medievales", 15 (1985), pp. 159-161, ambos trabajos se insertan en "De Historia Judía Hispánica, Homenaje dedicado por la Universidad de Barcelona al Profesor David Romano Ventura", en "Collecció Homenatges", 6, Barcelona, 1991, pp. 341371 y 373-399).

${ }^{23}$ Francisco GARCía FITZ, La frontera castellano-granadina a fines del siglo XIII, en "Actas del IV Coloquio de Historia Medieval Andaluza: Relaciones exteriores del reino de Granada", Almería, 1988, pp. 23-35, La defensa de la frontera del bajo Guadalquivir ante las invasiones benimerines del siglo XIII, en "Relaciones de la Península Ibérica con el Magreb. Siglos XIIIXVI", Madrid, 1988, pp. 275-323 y Castilla y León frente al Islam. Estrategias de expansión y tácticas militares (Siglos XI-XIII), Sevilla, 1998, pp., 28, 38, 82, 97, 273, 288, 289, 332, 333 , donde se destaca la enorme importancia estratégica de Tarifa, para musulmanes y cristianos.
} 
comercio con Portugal. Igualmente, según hemos podido ver, la guerra contra los benimerines requería muchos esfuerzos, humanos y económicos.

Sin embargo, a nuestro entender, lo que verdaderamente estaba amenazada era la condición realenga del concejo de Niebla. Así, no parece fortuito que, como dijimos, el 2 de julio de 1293, el concejo de Niebla pidiese a Sevilla traslado de todos sus privilegios, franquezas y mercedes reales ${ }^{24}$, sino porque era consciente de que corría peligro de caer en manos de un señor, cuando, por ejemplo, ese mismo año 1293. Sancho IV había concedido el señorío, todavía vitalicio, de Huelva a su camarero mayor, don Juan Mathe de Luna $^{25}$ y también, por entonces, había hecho merced, aunque ésta no se hizo efectiva, de Palos al almirante Pay Arias Cherino ${ }^{2 n}$.

Todo parece indicar que la causa eficiente de la fortuna de éstos y de otros señores fue, sin duda, su muy activa participación - sobre todo de don Juan Mathe de Luna- en todo lo relativo la defensa de Tarifa ${ }^{27}$. Como también sería de la de don Alfonso Pérez de Guzmán, el heroico defensor de la plaza, fundador del linaje de los condes de Niebla, quien recibiría su recompensa con el señorío de Sanlúcar de Barrameda, ya en el reinado de Fernando IV ${ }^{28}$.

Sin embargo, en el fondo, todo ello sólo era parte de un amplio proceso de enajenación del realengo, protagonizado por la corona y que tenía como fin garantizar el apoyo de aquéllos que estaban más próximos al rey, constituidos en élite nobiliaria ${ }^{29}$. Sea como fuere, este proceso, iniciado por Sancho IV, proseguiría, como tendremos ocasión de ver para el caso de Niebla, en el reinado de su heredero, Fernando IV.

\footnotetext{
${ }^{24}$ ADMS, Legs. 345 y 740.- Miguel Ángel LADERo QUESADA, Niebla, de reino a condado. cit. p. 26, n. 23 .

"5ADMS, Leg. 680.- Miguel Ángel LADERO QUESADA. Niebla, de reino a condado. cit.. p. 36. n. 60 .

"ADMS, Leg. 734.- Miguel Ángel LADERo QUESADA. Niebla, de reino a condado. cit. p. 36. ก. 59.

${ }^{27}$ Mercedes GaibroIS DE Balli:steros. Tarifa y la politica de Sancho IV de Castilla. Madrid. 1920 (tirada aparte del "Boletín de la Real Ácademia de la Historia", vols. LXXIV a LXXVII).

¿Xauel GonZÁlez JimÉnEz. Gużmin el Bueno y su tiempo, "Les Espagnes Médiévales. Aspects économiques el sociaux. Mélanges offers a Jean Gautier Dalché" |"Annales de la Faculté des Lettres et Sciences Humaines de Nice". 46 (1983)].

"José Manuel Nieto Soria. Sancho IV. 1284-1295. en "Corona de España". III. cit., pp. $175-178$ y $190-201$
} 


\section{FERNANDO IV (1295-1312) Y LA DIFICII. RESISTENCIA}

La minoridad de Fernando IV (1295-1303) también fue un período lleno de dificultades para el concejo realengo de Niebla, tanto en lo que se refiere a su propia consolidación interna, como a su proyección exterior. realidades ambas que tuvieron, como telón de fondo, uno de los numerosos episodios que formarían parte de la coyuntura depresiva que habría de prolongarse a lo largo de todo el siglo XIV ${ }^{30}$.

Los problemas institucionales de Niebla pueden observarse, por ejemplo, en su relación directa con la corona, a través de las sucesivas confirmaciones de sus privilegios reales. Así, si la primera de la que tenemos noticias, fechada en Valladolid, el 8 de agosto de 1295, y firmada por los tutores del nuevo monarca, tiene el carácter consuetudinario de todos los inicios de reinado ${ }^{31}$, las que le siguieron, en 1296, en 1298 y en 1299. parecen demostrar, sin duda, un incumplimiento sistemático de estos privilegios $^{32}$. Igualmente, el 12 de abril de 1300, en Ciudad Rodrigo, Fernando IV, a petición del concejo de Niebla, le permite incluir en su fuero algunas leyes tomadas del Fuero de Jerez y otras del Fuero de Sevilla. concretamente las relativas a los adulterios de moros y judíos con cristianas y a los que quebrantaren treguas o aseguranzas ${ }^{33}$.

En este mismo sentido, debe verse la merced concedida al concejo de Niebla, en las Cortes de Valladolid de 1295, por los tutores de Fernando IV, de que pudiera emplear todas las limosnas, recaudadas con el fin de redimir a los cautivos de las campañas llevadas a cabo por Sancho IV contra

\footnotetext{
"Muchos datos generales en quien. tal vez. es el mejor conocedor del problema: Julio VALDEÉN. Aspectos de la crisis castellana de la primera mitad del siglo XIV. "Hispania". III (1969). pp. 5-24. La crisis del siglo XIV en Castilla: retisión del problema. "Revista de la Univerșidad de Madrid". 79 (1972). pp. 161-184. Reflexiomess sobre la crisis bajomedieval e'l Castilla. "En la España Medieval". 5 (1984). pp. 1047-1060. Las crisis del siglo XIV en la Corona de Castilla. "Homenaje a Marcelo Vigil Pascual". Salamancal. 1989. pp. 217-235. Algunos aspectos puntuales de la crisis en el reino de Sevilla en Isabel MonTES ROMiroCamacho. Propiedad ye explotacioin de la tierra en la Sevilla de la Baja Edad Media. Sevillia. 1988.

"Miguel Ángel LADERO QUESADA. Niebla, de reino a condudo. cit. p. 27. nota 25.

"Miguel Ángel LADERO QUESADA. Niebla, de reino a conderde, cit. p. 27. notas 26 y 27. una fue expedida el 16 de agosto de 1296, en León. otra el 23 de enero de 1298. en Valladolid $y$ la otra el 5 de mayo de 1299. en Plasencia.

"Antonio BENAvides. Memorias del reinado de D. Fernando IV de Castilla. II. Colección Diplomática. Madrid. 1860. doc. CLV. pp. 210-211.
} 
Granada, sin que les fuesen demandadas por los receptores de la bula de cruzada $^{34}$.

Algo similar puede decirse en lo que hace a la política de Fernando IV en relación a los judíos, que, además de por otros muchos testimonios, puede seguirse a través de las resoluciones tomadas al respecto en las Cortes. Mencionaremos, a continuación y de forma muy resumida, únicamente aquéllas que se refieren a su posición económica. Ya el 8 de agosto de 1295, en las Cortes de Valladolid, se apartaba a los judíos de todo oficio de la casa real, así como de la recaudación de impuestos ${ }^{35}$, mientras que el 15 de abril de 1299, en unas nuevas Cortes de Valladolid, se prohibía a los judíos que tuvieran su propio entregador, con lo que la recaudación de las deudas judiegas debería llevarse a cabo por dos alcaldes de la villa correspondiente o por el juez, al tiempo que se fijó el plazo de caducidad de los pagarés en seis años ${ }^{36}$. Ya el 10 de mayo de 1301, en las Cortes de Burgos, Fernando IV prohíbe a los judíos que actuen como arrendadores y recaudadores de los servicios, al tiempo que vuelve a reiterar la orden de sean los alcaldes locales y merinos los encargados de recaudar las deudas de los judíos, como en tiempos de Fernando III y de Alfonso $\mathrm{X}^{37}$.

Sin embargo, podemos observar una clara transformación de la actitud, ciertamente dura, de Fernando IV hacia el papel económico desempeñado por los judíos en el reino de Castilla, en torno a 1300, tal vez motivado por los acuciantes problemas financieros que empezaron a plantearle sus obligaciones militares. De esta manera, ya en las Cortes de Valladolid de 1300, cuyas resoluciones no se nos han conservado, el monarca tuvo que aceptar, nuevamente, que hubiese un entregador especial de las deudas de los judíos - lo que justifica por el hecho de haber solicitado en ellas el pecho de los judios- al tiempo que, a causa de la guerra, prolongaba el tiempo de validez legal de los pagarés de seis a nueve años, situaciones, junto a la posibilidad de que los judíos siguieran siendo arrendadores de los impuestos reales, que el monarca defendió, a pesar de las protestas de los procuradores, en las Cortes de Zamora, reunidas en

\footnotetext{
${ }^{34}$ Miguel Ángel Ladero QueSADA, Niebla, de reino a condado, cit., p. 30, nota 41.

${ }^{35}$ Cortes, I, p. 131.- Fritz BAER, Die juden im christlichen Spanien, cit., doc. 103, p. 97.

${ }^{36}$ Cortes, I, p. 131.- Fritz BAER, Die juden im christlichen Spanien, cit., doc. 107, p. 98. 101.

${ }^{37}$ Cortes, I, p. 145 y s.- Fritz BAER, Die juden im christichen Spanien, cit. doc. 111, p.
} 
agosto de $1301^{38}$. Nuevamente, el 3 de junio de 1302, en las Cortes de Medina del Campo, el rey vuelve a justificar el hecho de que pueda servirse de arrendadores y recaudadores judíos por el estado en que se encontraba la hacienda real y la necesidad acuciante de socorrer la Frontera ${ }^{39}$. Esta misma actitud regia continuó en los años siguientes, cuando, por ejemplo, en 1304, Fernando IV confirmó los privilegios de los judíos castellanos que, a cambio, aceptaron pagarle un servicio extraordinario, al tiempo que reglamentaba todo lo relacionado con los préstamos y el cobro de deudas, por parte de los judios ${ }^{40}$.

Nuevamente, las cosas cambiaron cuando el 8 de junio de 1305, en las Cortes de Medina del Campo, Fernando IV volvió a prohibir que los judíos fuesen arrendadores o recaudadores de impuestos, así como que hubiese entregadores de las deudas de los judíos ${ }^{41}$, prohibiciones, junto a la confirmación de las leyes de Alfonso X y Sancho IV sobre el tipo de interés de los judíos, que volvió a reiterar en las Cortes de Valladolid, el 29 de junio de $1307^{42}$.

Por todas las razones anteriores, que nos muestran -además de la tradicional política ambigua de la monarquía castellana con relación a los hebreos - un progresivo empeoramiento de las relaciones entre la corona y la comunidad judía de Castilla, no es extraño que, finalmente, el 24 de abril de 1312, en las Cortes de Valladolid, Fernando IV se quejara de que la desidia y la falta de rigurosidad en su recaudación habían rebajado a una quinta parte, en relación a lo recaudado en épocas de Alfonso X y de Sancho IV, el principal impuesto pagado al fisco regio por los judíos castellanos: la cabeza de pecho, lo que, según se decía, era debido a la situación de privilegio que disfrutaban los hebreos ricos, aunque la realidad, al parecer,

\footnotetext{
${ }^{38}$ Cortes, I, p. 151 y s.- Fritz BAER, Die juden im christlichen Spanien, cit., doc. 113, pp. 102-103. 103.

${ }^{39}$ Cortes, I, p. 161 y s.- Fritz BAER, Die juden im christlichen Spanien, cit., doc. 115, p.

${ }^{40}$ La carta real está fechada en Soria, el 16 de agosto de 1304 (José Rodríguez MoLinA, Colección Diplomática de Baeza (siglos XIII-XV), Jaén, 1983, doc. 12, citado por Miguel Ángel LADERO QUESADA, Fiscalidad y poder real en Castilla (1252-1369), cit., p. 79, nota 97).

${ }^{4 C}$ Cortes, I, p. 172 y s y 179 y s.- Fritz BAER, Die juden im christlichen Spanien, cit., doc. 119, p. 109 114.

${ }^{42}$ Cortes, I, p. 191, 195.- Fritz BAER, Die juden im christlichen Spanien, cit., doc. 123, p.
} 
no era otra que el paulatino empobrecimiento de las aljamas de Castilla, al que no sería ajena la de la Niebla ${ }^{+3}$.

Es, precisamente. en este contexto donde debemos situar algunos testimonios que nos hablan de la relaciones entre los vecinos de Niebla y los financieros judíos, bien fueran algunos personajes muy importantes, por el papel que desempeñaban al lado del monarca, como otros hebreos que componían la aljama de Niebla y que, por tanto, eran vecinos de este concejo realengo desde los primeros tiempos de su repoblación.

De esta manera, el 6 de febrero de 1306, en Niebla, tuvo lugar una composición entre el concejo y algunos representantes de la aljama de los judíos, con el fin de solventar los problemas derivados del reintegro de los préstamos otorgados por los judíos de Niebla a los vecinos de la villa ${ }^{H}$.

Por lo que sabemos. Fernando IV había recibido las quejas de la aljama de los judíos de Niebla y de don Judah Abravanel (¿de Sevilla?) justificando el no haber pagado a la corona los sus pechos e los sus pedidos, debido al vacío de autoridad que padecía el concejo de Niebla, ya que carecía, en ese tiempo, de alcaldes, por lo que pidieron al rey que designase a quienes pudieran remediar la situación. Con este fin, entender en todo lo relativo a las deudas contraidas por los cristianos con los judíos, fueron nombrados dos vecinos de Niebla, Amado Díaz y Velasco Martínez. Esta decisión regia fue acatada fielmente por el concejo de Niebla, que, teniendo en cuenta "commo el estado de la tierra era muy menguado e los vezinos muy pobres e muy endebdados e que podién seer derraygados, et entendiendo que es seruiçio de Dios e del rey nuestro sennor e pro de la tierra". aceptó llegar a un acuerdo con los representantes de la aljama de los judíos

\footnotetext{
${ }^{43}$ Cortes. I. pp. 217, 220.- Fritz BAER. Die jueden im christlichen Spunien. cil. doc. 132. pp. 117-118.- Miguel Ángel LADERO QUESADA. Fiscalidad y poter real enl Castilla (1252. 1369). cit. pp. 78-79. nota 97: Según parece. en 1304. Fernando IV habia tratado de hacer cumplir a los judios castellanos el pago de sus contribuciones, obteniendo de ellos un servicio extraordinario, como contrapartida de normalizar su actividad como prestamistas y el cobro de deudas IJosé Rodriguez Molina. Colección Diplomática de Baeza (Siglos XIII-XV). Jaén. 1983. doc. 12. carta enviada desde Soria. el 16 de agesto de 1304|.

"Documento II del Apéndice: AHN. Diversos. Concejos y ciudades. carp. 3. n. 111 (I). Cit. Miguel Angel LADERO QUESADA. Niebla, de reinn a comededo. Nonicias solmre el Algarbe andalus én la Baja Edad Media. Madrid. 1992. pp. 29-30. nota 38. según una copia existente en el ADMS. Leg. 345.
} 
de Niebla, tanto vecinos como moradores de la villa y su término, don Çag Arramat, don Fraym Alfandarí y don Çulemán Portugalés ${ }^{45}$.

Según esta concordia, los deudores cristianos, vecinos y moradores de la villa de Niebla y de su término, se comprometían a pagar la mitad de sus deudas a la fecha del convenio y la otra mitad en septiembre siguiente. el día de San Miguel, es decir, el 29 de septiembre. Por su parte. los judíos prestamistas renunciaban a percibir interés, hasta el día de San Miguel. por haber estado de acuerdo en aplazar estas deudas. Sin embargo, sí estaban autorizados a cobrar la pena estipulada por el aplazamiento de cualquier otro débito. legalmente reconocido, anterior a los plazos convenidos en el acuerdo.

Por su parte, los judíos, don Çag, don Fraym y don Çulemán, en su propio nombre y en representación de los vecinos y moradores de la aljama de Niebla, también adquieren el compromiso de solventar cualquier deuda contraída con los cristianos, sometiéndose, igualmente. al juicio de los dos vecinos de Niebla. Amado Díaz y Velasco Martínez, diputados como jueces para la ocasión.

Por último, hay que reseñar la originalidad de este documento, ya que se hicieron de él dos cartas partidas por abc, una para el concejo, con las firmas, en hebreo, de don Çag Arramat, don Fraym, don Çulemán y el rabí Salomón, y la otra para la aljama de los judíos de. Niebla, autentificada con el sello colgado del concejo de Niebla ${ }^{\text {th. }}$.

Pero, ¿quiénes eran estos judíos que aparecen en el documento?. Ciertamente no es fácil identificarlos, sobre todo a los vecinos de Niebla, ya que. como es lógico, su proyección económica se reducía, más bien, al

\footnotetext{
"Evidentemente, a lo largo de todo el reinado de Fernando IV. Niebla hubo de soportar innumerables problemas de iodo tipo. Io que repercutió directamente en el fracilso de la repoblación de su término y dió paso al inicio de su proceso de señorialización (Miguel Ángel LADERO QUESADA. Niebla, de reino a condedo. cit., pp. 29-40), algo que. desde luego. cra común a gran parte del reino de Sevilla (Manuel GONZAi.FE JiNÉNEZ. La repoblacion de la soma de Sevilla duramte el sigho XIV. Sevilla. 1993 (2“a ed.). - Isabel MONTES ROMERO-Canacho. Propiedad y explotación de la tierra en la Serilla de la Baja Edad Media. Sevillia. 1988 y El paisaje rural serillamo en la Baja Edad Media. Sevilla. 1989).

thAHN, Diversos. Concejos y ciudades. carp. 3, n. 111 (I). Cit. Miguel Ängel L.ADERO QUESADA. Niebla, de reino a condado. Noticias sobre el Algarbe andalus en la Baja Edad Metict. Madrid. 1992. pp. 29-30. nota 38. según una copia existente en el ADMS. Leg. 345. en el documento. las firmas se escriben en árabe. utilizando letras hebreas. Dehemos su transcripción al Dr. D. José Luis Lacave. del Instituto de Filologia de CSIC (Madrid), a quien mostramos toda nuestra gratitud: "Yo Ishay ben Abramat testigo.- Yo Efraim ben Alfandari testigo.- Yo Suleimán ben Absalulán testigo.- Yo Silomón.
} 
ámbito local. Cosa distinta ocurre con don Yhude Abrauaniel, cuyo segundo apellido no es legible en el documento.

Así pues, por lo que sabemos, este don Yhude Abrauaniel, podría ser, con mucha probabilidad, don Judah Abravanel de Sevilla, uno de los principales personajes judíos de la Sevilla de Fernando IV, a quien sirvió como almojarife de la ciudad, por lo que es perfectamente explicable su actuación, junto a los judíos de Niebla, en la recaudación de los impuestos correspondientes a la corona, ya que Niebla, como concejo de realengo, dependía de los almojarifes reales sevillanos. Igualmente, don Judah desempeñó un brillante papel, al lado de la corona, en relación a la guerra contra los musulmanes, encargándose, en 1310, de todo lo relativo a la infraestructura económica del cerco de Algeciras. Su magnífica posición, al lado de la familia real, continuó una vez muerto Fernando IV, ya que, por ejemplo, sirvió como prestamista al infante don Pedro, tutor de Alfonso XI. Por último, sólo nos queda decir que don Judah fue, tal vez, quien dió comienzo a la rama sevillana de la poderosa familia de los Abravaneles o Abarbaneles, de origen toledano, muchos de cuyos miembros salieron de Castilla tras los acontecimientos luctuosos de 1391. Uno de los más importantes sucesores de don Judah fue don Samuel Abravanel de Sevilla, que alcanzó una enorme fama en el reino, tanto por sus riquezas y su sabiduría, como por su importante posición junto a Juan I de Castilla, de quien llegaría a ser contador mayor, puesto que conservaría en el reinado de Enrique III, tras convertirse al cristianismo, tomando el nombre de Juan Sánchez de Sevilla ${ }^{47}$.

En cuanto a los judíos de la aljama de Niebla firmantes del acuerdo con el concejo, todo parece indicar que se trata de miembros de familias hebreas avecindadas en esta villa, en algunos casos, desde hacía tiempo, posiblemente desde la misma época de su repoblación, y que, tal vez, procedían de otras ciudades previamente repobladas, como Sevilla o Jerez,

\footnotetext{
${ }^{47}$ Antonio Benavides, Memorias del reinado de D. Fernando IV de Castilla, cit., II, Colección Diplomática, Madrid, 1860, doc. DXXV, pp. 760-763.- José AMADOR DE LOS Ríos, Historia social, política y religiosa de los judios de España y Portugal, cit., pp. 318-319.- Fritz BAER, Die juden im christlichen Spanien, cit., doc. 128, p. 116.- Yitzhak BAER, A History, cit. I, pp. 309 y 378.- Isabel MONTES ROMERO-CAMACHO, Notas para el estudio de la judería sevillana en la baja Edad Media (1248-1391), cit., pp. 11 y 24 y Juan Sánchez de Sevilla, antes Samuel Abravanel, un modelo de converso sevillano anterior al asalto de la judería de 1391. Datos para una biografía, en "Aragón en la Edad Media". XIV-XV (Homenaje a la profesora Carmen Orcástegui Gros), Universidad de Zaragoza, 1999, pp. 1099-1113.
} 
lo que, quizás, pudo ocurrir con los antepasados de don Çag Arramat ${ }^{48}$ y de don Fraym Alfandari ${ }^{49}$, mientras otros, como don Çuleymán Portugalés, procedían del vecino reino de Portugal y habrían llegado a Niebla no sólo por razones proximidad geográfica y por las fluidas relaciones - políticas y familiares- de ambas coronas, castellana y portuguesa, sino atraídos por el papel fundamental que la villa desempeñaba, tanto dentro del reino de Sevilla, como en la guerra contra los musulmanes, todo lo cual les ofrecía magníficas perspectivas económicas ${ }^{50}$. De la misma manera, con el objetivo, sin duda, de sancionar el acuerdo desde el punto de vista religioso, el documento también fue firmado por rabí Salomón, en su condición de autoridad espiritual de la aljama de Niebla.

No obstante, la composición entre el concejo de Niebla y la aljama de los judíos del lugar no debió cumplirse en su totalidad, ya que el 6 de septiembre de 1307, desde Burgos, Fernando IV mandaba que aquéllos que debían dinero a los judíos, sólo estarían obligados a devolver dos tercios del total, mientras que el interés o ganancia podrían pagarlo en tres plazos ${ }^{51}$. Esta decisión regia no sólo nos reitera el cambio de actitud de Fernando IV en relación a los judíos, que, como hemos dicho, volvió a confirmarse en las Cortes de Valladolid de 1307, sino también el proceso de decadencia irremediable en el que se veían sumidos muchos concejos realengos castellanos y, en el caso que nos ocupa, el de Niebla, deterioro tal vez

\footnotetext{
${ }^{48}$ Manuel GonZÁlez JimÉnEZ y Antonio GonZÁlez GómEZ, El libro del repartimiento de Jerez de la Frontera. Estudio y Edición, Cádiz, 1980, n⿳s 1891,1892 y 1893 . en el repartimiento urbano de Jerez de la Frontera, llevado a cabo alrededor de 1266, aparece un Çag/Zag Arromis y lo mismo en Fritz BAER, Die juden im christlichen Spanien, cit., doc. 76, p. 59, esta vez como Çag Arromiz.

${ }^{49}$ En 1285, Çag Alffandan era propietario de viñas en los alrededores de Sevilla (Pilar Ostos y $\mathrm{M}^{\mathrm{a}}$ Luisa PARDO, Documentos y notarios de Sevilla en el siglo XIII, Madrid, 1989, doc. 85 , p. 323); en 1369, don Abrahem Alfandary era procurador del conocido almojarife sevillano don Çulemán Aben Ataheb (Isabel MONTES Romero-CAMACHO, Notas para el estudio de la judería sevillana en la baja Edad Media (1248-1391), cit., p. 272), don Yuçef de Toledo Alfandary era vecino de Sevilla, en 1480 (Isabel MONTES ROMERO-CAMACHO, Los judios sevillanos (1391-1492). Del asalto a la expulsión. Datos para una prosopografía, en "Actas de las III Jornadas Hispano-Portuguesas de Historia Medieval. La Península Ibérica en la era de los Descubrimientos. 1391-1492", Sevilla, 1997, pp. 165-257, ver, especialmente la p. 256, n 255). - Manuel GONZÁLEZ JimÉNEZ y Antonio GONZÁLEZ GómEZ, El libro del repartimiento de Jerez de la Frontera. Estudio y Edición, n's 1888, 1889, 1890, 1891 y 1926, en el repartimiento urbano de Jerez de la Frontera, llevado a cabo en torno a 1266, aparece un Zag Albardan.

${ }^{50}$ Florentino PÉREZ-EMBID, La frontera entre los reinos de Sevilla y Portugal, cit. pp. 76-83.

${ }^{51}$ Miguel Ángel LADERo QUESADA, Niebla, de reino a condado, cit. p. 30, nota 39, documento en el ADMS, Leg. 345.
} 
empeorado por las duras exigencias fiscales por parte de la corona y, muy pronto, por las terribles consecuencias de la ola de calor que Castilla padeció en el verano de 1307, que propició el subsiguiente rosario de calamidades bajomedievales, entre las que hay que destacar la epidemia de peste que afectó a gran parte del reino ${ }^{52}$.

Esta situación de crisis se vió agravada, como es lógico, a partir de 1309, debido a la presiones que el concejo de Niebla sufrió, por parte de la corona, para que hiciese frente a sus obligaciones, tanto militares como económicas, con relación a la campaña de Algeciras. De esta manera, el 2 de octubre de 1309, desde el sitio de Algeciras, Fernando IV recordaba, con cierta dureza, a los caballeros de Niebla, su obligación, como concejo de realengo, de servir en la hueste real, ante la evidencia de que muchos de ellos se habían convertido en vasallos nobiliarios, lo que, desde luego, iba en detrimento de la condición realenga de Niebla ${ }^{53}$. La inhibición del concejo llegó a tal límite que no aportó los doscientos cahíces de trigo que le habían correspondido para contribuir al abastecimiento de Gibraltar, por lo que el Adelantado ${ }^{54}$ Fernán Pérez Ponce ${ }^{55}$ había ordenado el embargo

\footnotetext{
"'César Gonzallez Minguez. Fermande IV (/295-13/2). en "Corona de España". IV. Palencia. 1995. pp. 171-179. entre otras muchas quejas presentadas por los procurades castellanos a Fernando IV estaba la de que el rey habia ordenado cobrar. en 1305 y 1306. servicios y tributos sin la aprobacion previa de las Cortes. Esta arbitrariedad regia se unicial estado de pobreza en que se encontraba Castilla, ya que "la tierra era muy yerma y muy pohre". además de que. por esos años "guerra ninguna no avia". que justificase tales abusos. Fernando) IV aceptó las quejas de los procuradores y se obligó. entre otras cosas, a no ordenar cobrar ningún pecho sin el previo consentimiento de las Cortes. De la misma manera. el rey se comprometió a que todos los tributos reales fueran recaudados por hombres buenos de las villas. ricos y abomados y no por judios. Sea como fuere. las quejas de los procuradores de Valladolid advirtieron a Fernando IV del peligro que corria la monarquia si no conservaba su alianza con las ciudades y cedia a las presiones de la nobleza. por lo que el rey intento poner en práctica las medidas pertinentes para. en lo posible. evitar el empobrecimiento del reino y las amenazas que. por parte de los señores y con la anuencia de la corona. padecian los concejos realengos. Por ello. entre otras cosas. prometio respetar todos los fueros y privilegios de las villas y aminorar la presión fiscal. para evitar la luuida de muchos pecheros a lierras de señorio. garantizar la elección de los oficios concejiles entre los vecinos, devolver a los concejos sus aldeas y términos usurpados...

${ }^{53}$ Miguel Ángel LADERo QUESADA. Niebla, de reimo a comdado, cit. p. 31. nota 42. documento en el ADMS. Legs. 345 y 741 .

${ }^{54}$ Según algunos autores. como Rogelio PEREZ BUSTAMANTE. El gobiermo y la administr(1cion de los reinos de la corona de Castilla (1230-1474). cit.. II. p. 304, podria tratarse de infante don Juan, tio del rey. que asumio el cargo de Adelantado Mayor de la Frontera entre 1306-1311. - Diego ORTI\% DE ZUÑ̈IG. Anales de Sevilla, cil.. 2. año. 1396. cap. 5. p. 256. en 1311 era Adelantado Mayor de la Frontera el infante don Juan. hijo del rey don Alonso el Silbio.
} 
de las rentas y bienes de propios de la villa, entre los que destacaban los almojarifazgos que Niebla, otra vez a imitación de Sevilla, recaudaba en las aldeas de su alfoz ${ }^{56}$. No fue hasta el 10 de diciembre de 1310, en Niebla, cuando, tras llegar a un acuerdo con el Adelantado mediante el cual Niebla pagó los 20.000 maravedíes, correspondientes al coste de 150 cahíces de trigo, en lugar de los 200 a que estaba obligada, éste le restituyó el disfrute de sus propios. En su descargo, el concejo adujo su terrible situación, debida, entre otras cosas, a sus contribuciones a la campaña de Algeciras de 1309. las que había llevado a cabo, anteriormente, en ocasión de la guerra de Portugal, "en las armadas y en las guardas de los panes", así como el dinero gastado en atender a su propia defensa, con el mantenimiento de su muralla y alcázar ${ }^{57}$.

Pero si problemático resultaba al concejo de Niebla hacer frente a sus propias obligaciones como concejo de realengo, igualmente difícil le era garantizar algo tan esencial para afirmar su misma condición realenga como era el mantener bien poblado su amplio alfoz, más aún cuando cada vez eran más numerosos los enclaves señoriales en sus proximidades ${ }^{58}$.

\footnotetext{
${ }^{55}$ Miguel Ángel LADERO QUeSADA, Nielhla, de reino a condado. cit. p. 31. nota 44. documento en el ADMS. Legs. 345 y 741 . parece referirse a don Fernán Pérez. Ponce (de León). primer señor de Marchenal hijo de don lecrnín Pérez Ponce de León. quien fue Adelantado de Andalucía, por Sancho IV. desde 1285 hasta 1294. posiblemente. según Diego OrTiz deZ ZúNiga, Anales de Sevilla, cit. 2. p. 255.- Rogelio PÉREz Bustaniante. El gobierno y la administración de los reinos de la coroma de Castilla (1230-1474). cit. II. p. 307. documenta a Fernán Pérez Ponce como Adelantado Mayor de la Frontera. con Sancho IV. entre 1290-1291.- Neticias sobre don Fernán Pérez. Ponce (de León), primer señor de Marchena. en Diego OrTIZ DE ZúÑiga. Anales de Sevilla, cit.. 2, pp. 26, 36, 38.39 (el 18 de diciembre de 1309. Fernando IV le concede el señorio de Marchena. por mumchos servicios que vos me ficistes, e me facedes en la cerca cure vo fice sobre Algesira). 44, 47, 68.69. 71, 78, 255. Ratael Sanchez SaUS. Limajes sesillamos meedievales. (omo I. p. 232. Linaje LXIII. reseña n" 8) de don Fernán Pérez. Ponce. hijo de lernín Pérez. Ponce $(+1291)$ y de Urracal Gutiérrez de Meneses y marido de Isabel de Guzmán. muerto en lorno al 1310 (no corincide. en la fecha do fallecimiento, con Diego OrTr\% DE Zúñiga. que. lal vez. lo confunde con su hijo. de igual nombre. muerto en 1355) y tomo Il. pp. 402-403.

"Miguel Ángel LADERO QUeSADA. Los propios de Sevilla (1486-1502). en "Los mudéjares de Castilla y otros estudios de historia medieval andaluza". Granada. 1989. pp. 313-346.

${ }^{57}$ Miguel Ángel LADERO QUeSADA. Niella. de reino a comdado. cil. p. 31. nota 43. documento del ÃDMS. Legs. 345 y 741 .- Sobre el sitio de Algeciras y la connquista de Gibraltar, ver, entre otros estudios del mismo autor. por ejemplo la síntesis de César Gonzallez Mínguez. Fernando IV (1295-1312), en "Corona de España". IV. Pallencia. 1995. pp. 214-224.

${ }^{58}$ Miguel Ángel Ladero QUeSADA. Niebla, de reino a comededo. cit. pp. 34-40: poco a poco. al igual que le ocurrió a Jerez. Ios numerosos señorios que io rodeaban fueron produciendo la asfixia del concejo de Niebla. que ni tan siquiera pudo contar con una salida al mar. como seria Cádiz para Jerez. Sin eimbargo. durante los reinados de Alfonso XI (1312. 1350) y Pedro I (1350-1368) Iodavía siguió conservando su importancia como concejo realengo.
} 
Así, desde 1309, la documentación se refiere, muchas veces de manera reiterativa, a los heredamientos vagados de Niebla, por lo que, tanto Fernando IV, en 1309, lo que pudo ser todavía una consecuencia directa de los acuerdos tomados por las Cortes de Valladolid de 1307, como el infante don Pedro, tutor de su sobrino Alfonso XI, en 1313, a petición del concejo de Niebla, designaron partidores que, en los años siguientes, se encargaron de llevar a cabo los nuevos repartos de tierra, especialmente en aquellos lugares del término peor poblados, como era el caso de los territorios fronteros con Portugal o con los nacientes señoríos ${ }^{59}$.

Como era de esperar, todos estos problemas fueron, a la vez, causa y consecuencia de los duros enfrentamientos internos que tuvieron lugar, dentro del concejo de Niebla, entre caballeros y hombres buenos, que habrían de hacerse crónicos en todo el reino de Sevilla, como consecuencia de la crisis política que se vivió durante el primer siglo de la repoblación y, especialmente, por la terrible confusión política provocada por la larga minoría de Alfonso XI. Estas luchas intestinas habrían de saldarse con el rotundo triunfo de los caballeros, que terminarían por hacerse con el dominio de los concejos, en toda Andalucía, ya en el reinado efectivo de Alfonso XI. Así pues, los primeros síntomas de estas tensiones en el concejo de Niebla, podemos percibirlos, por ejemplo, en 1306, cuando, según sabemos, al parecer, algunos importantes cargos concejiles, como los alcaldes, no estaban cubiertos, lo que provocaba grandes dificultades en el ejercicio de la justicia, que, evidentemente, repercutían en la autoridad y fiscalidad regias $^{60}$. Y también, como hemos dicho, en 1309, cuando las contradicciones internas en el concejo de Niebla por el monopolio de los cargos concejiles, provocaron, entre otros muchos desastres, la dejación del

justificada tanto por la amplitud de su territorio como por sus notables prerrogativas políticas y administrativas.

${ }^{59}$ Miguel Ángel Ladero QueSADA, Niebla, de reino a condado, cit., pp. 31-34.

${ }^{60}$ Documento II del Apéndice: AHN, Diversos. Concejos y ciudades, carp. 3, n. 111 (I). Cit. Miguel Ángel LADERO QUESADA, Niebla, de reino a condado. Noticias sobre el Algarbe andaluz en la Baja Edad Media, Madrid, 1992, pp. 29-30, nota 38, según una copia existente en el ADMS, Leg. 345: "Sepan quantos esta carta vieren commo nos el conçeio de Niebla, veyendo las cartas de nuestro sennor el rey don Ferrando em que nos enbió dezir e mandar que sobre querellas quel aljama de los judíos de Niebla et don Yhude Abrauaniel (ilegible) se le enbiaron querellar que por razón que en la villa de Niebla que non auién alcalles que ellos non podién auer lo que les deuién para pagarle los sus pechos e los sus pedidos, e quel pedieran merçed que les diese quien gelo librasse, et por razón que Amado Díaz e Velasco Martínez, nuestros vezinos, le dixeran que eran omnes que lo sabrían fazer, que tenién por bien que lo librassen lo que deuién los christianos a los judíos, segunt las sus cartas del rey diçen..." 
concejo ilipense en el cumplimiento de sus obligaciones militares, con respecto a la corona ${ }^{61}$.

\section{ALFONSO XI (1312-1350) \\ Y EL PRINCIPIO DEL FIN DE NIEBLA COMO CONCEJO DE REALENGO}

Desde el punto de vista de la normativa canónica, la minoría de Alfonso XI estuvo marcada por un avance imparable de la mentalidad antijudía, claramente perceptible en el Concilio de Vienne, convocado por Clemente V en 1311, realidad que se vió acentuada en el reino de Castilla, con la denominada hispanización de los cánones de Vienne ${ }^{62}$, lo que tuvo lugar en los ordenamientos del Concilio Provincial de Zamora contra los judíos, el 11 de enero de $1313^{63}$.

Como era de esperar, esta toma de postura, por parte de la autoridad eclesiástica, dió paso a un mayor deterioro, al menos a nivel oficial, de las relaciones entre cristianos y judíos, algo que aparece, con toda claridad, en la legislación promulgada por las Cortes de Castilla, institución que alcanzó un enorme poder por estos años, como consecuencia del papel representado por las ciudades castellanas durante la minoridad de Alfonso $\mathrm{XI}^{64}$.

Así, el 5 de junio de 1313, en Dueñas, el infante don Juan, tutor de Alfonso XI, refrendaba los acuerdos tomados al respecto por las Cortes de Palencia $^{65}$, lo que también hicieron, el 15 de junio de 1313 , en Valladolid,

\footnotetext{
${ }^{61}$ Manuel García Fernández, El reino de Sevilla en tiempos de Alfonso XI (1312-1350), Sevilla, 1989, p. 158. - Miguel Ángel LADERO QUESADA, Niebla, de reino a condado, cit., pp. 30-31.- Rafael SÁNCHEz SAuS, Caracterización de la nobleza medieval en el área onubense, en "Huelva en la Edad Media. Reflexiones, aportaciones y nuevas perspectivas veinte años después", Universidad de Huelva, 1999, p. 41

${ }^{62}$ David Romano, Marco jurídico, cit. pp. 281-283.

${ }^{63}$ AHN, Toledo, Cat., Pap., leg. 634.- José AMADOR DE LOS Ríos, Historia social, política y religiosa de los judios de España y Portugal. cit. pp. 330-335 y 935-937.- Fritz BaER. Die juden im christlichen Spanien, cit., doc. 133, pp. 118-120: Ordenamientos del concilio provincial de Zamora contra los judíos, promulgados el 11 de enero de 1313.

${ }^{64}$ Luis SUÁREZ FERNÁNDEZ, Judios españoles en la Edad Media, cit. p. 147: "Lo que se inicia en 1312 es un esfuerzo, a través de las Cortes, para destruir los privilegios tras los que se protegían las aljamas..."

${ }^{65}$ Cortes, I, pp. 224, 227.- Fritz BAER, Die juden im christlichen Spanien, cit.,doc. 138, pp. $131-132$.
} 
la reina doña María y el infante don Pedro, igualmente tutores de Alfonso $\mathrm{XI}^{66}$. El 22 de julio de 1315, en las Cortes de Burgos, los tres tutores, de común acuerdo, además de confirmar las decisiones anteriores, limitaron enormemente la actuación finaciera de los judíos castellanos ${ }^{67}$, postura que, a petición de la Hermandad de Castilla, mantuvieron el 28 de marzo de 1317, en las Cortes de Carrión ${ }^{68}$ y, otra vez, el 6 de septiembre de 1318 , en las Cortes de Medina del $\mathrm{Campo}^{69}$. Ya el 8 de mayo de 1322, en Valladolid, el infante don Felipe, nuevo tutor de Alfonso XI, una vez muertos los infantes don Pedro y don Juan, en la frontera de Granada, en 1319, y doña María de Molina, en 1320, prosiguió, aunque más débilmente, esta política antijudía ${ }^{70}$.

Esta misma actitud antijudía se observa también en las decisiones contra los judíos adoptadas por el Concilio de Valladolid, el 2 de agosto de $1322^{71}$.

Entre otros muchos factores, esta postura oficial, tanto laica como eclesiástica, contraria a los judíos, era debida a la comprometida situación en que se encontraba el reino, ya que a la mala coyuntura económica, se unía la debilidad del poder real, durante la minoría de edad de Alfonso XI, especialmente a partir de la muerte de doña María de Molina. Esta realidad puede comprobarse una vez más, con toda precisión, en Niebla. Así, tenemos noticias de enfrentamientos constantes y luchas por el poder entre los caballeros y hombres buenos de Niebla, como los que tuvieron lugar en 1314 y 1315, situación de enorme desconcierto y debilidad del poder concejil que fue hábilmente aprovechada por algunos personajes que empezaban a consolidar su poder en el ámbito local con la posesión de un señorío, como fue el caso de Ruy Fernández de Robreda que, en 1315, logró hacer efectiva

\footnotetext{
${ }^{66}$ Cortes, I, pp. 241 s., 244.- Fritz BAER, Die juden im christlichen Spanien, cit., doc. 139, pp. 132-133.

${ }^{67}$ Cortes, I, pp. 272, 280 s.- Fritz BAER, Die juden im christlichen Spanien, cit., doc. 142 pp. 134-135.

${ }^{68}$ Cortes, I, pp. 307 s., 312 s.- Fritz BAER, Die juden im christlichen Spanien, cit., doc 144, pp. 137-138: Ello no fue obstáculo para que el rab don Mosse, junto a Iohan García, tuviese a su cargo la hacienda real castellana. Este Ravi don Mousi era despensero de la reina doña María de Molina.

${ }^{69}$ Cortes, I, p. 331.- Fritz BAER, Die juden im christlichen Spanien, cit., doc. 145, p. 138

${ }^{70}$ Cortes, I, pp. 338 s., 342, 351 s.- Fritz BAER, Die juden im christlichen Spanien, cit. doc. 147, p. 140

${ }^{71}$ Fritz BAER, Die juden im christlichen Spanien, cit., doc. 148, p. 141.
} 
la merced que le concediera Fernando IV de la aldea de Facanias, futura Valverde del Camino, con la consiguiente merma del alfoz de Niebla ${ }^{72}$.

Estos conflictos volvieron a reproducirse, con mucha más virulencia, en 1318, hasta el punto de que el mismo Adelantado de la Frontera ${ }^{73}$, Esteban Rodríguez Tenorio, se vió obligado a personarse en la villa, con objeto de restaurar el orden y la autoridad real, "para hacer escarmiento y enderezar la tierra y poner asosegamiento en la dicha villa...", situación de desgobierno que había llegado a provocar, incluso, la huida de numerosos vecinos a lugares señoriales próximos, como Gibraleón, señorío del linaje de La Cerda, y también a Portugal, donde se les ofrecía, sin duda, mejores condiciones de vida ${ }^{74}$.

De nuevo, en 1321, los linajes ilipenses volvieron a enfrentarse, esta vez debido a la activa participación el alcaide de la villa, Ruy Fernández de Gibraleón, en la conjura que, dirigida por el almirante Alfonso Jofre Tenorio, tenía como objetivo que Sevilla y su reino dejasen de reconocer la autoridad, como tutor de su sobrino Alfonso XI, del infante don Felipe y tomasen partido por el infante don Juan Manuel, quien también aspiraba a la tutoría. Los caballeros de Niebla se negaron a hacerlo y consiguieron expulsar a Ruy Fernández de Gibraleón del alcázar real de Niebla, con lo que la villa, de momento, volvió a reiterar su obediencia al infante don Felipe $^{75}$.

\footnotetext{
${ }^{72}$ Miguel Ángel LADERo QUESADA, Niebla, de reino a condado, cit., pp. 33-34 y Rafael SÁNCHEZ SAUS, Caracterización de la nobleza medieval en el cirea onubense, en "Huelva en la Edad Media. Reflexiones, aportaciones y nuevas perspectivas veinte años después", Universidad de Huelva, 1999, pp. 42 y 45.

${ }^{73}$ Rogelio PÉREZ BUSTAMANTE, El gobierno y la administración de los reinos de la corona de Castilla (1230-1474), II. Madrid, 1976, p. 308, en 1315 era Adelantado Mayor de la Frontera, por Alfonso XI, Men Rodriguez Tenorio.- Diego ORTIZ DE ZÚÑIGA, Anales de Sevilla, cit., 2, año, 1396, cap. 5, p. 256, expone la posibilidad de que, en 1313, Men Rodríguez Tenorio ejerciera como Teniente del Infante don Juan Manuel, Adelantado Mayor de la Frontera y Adelantado Mayor de Murcia.

${ }^{74}$ Miguel Ángel LADERo QUESADA, Niebla, de reino a condado, cit., pp. 27-28 y Rafael SÁNCHEZ SAUS, Caracterización de la nobleza medieval en el área onubense, cit., pp. 41-42.

${ }^{75}$ Miguel Ángel Ladero QueSADA, Niebla, de reino a condado, cit., pp. 28-29 y Rafael SÁnCHEZ SAUS, Caracterización de la nobleza medieval en el área onubense, cit., pp. 43-44. Muchas noticias sobre la participación de Niebla, junto a otras ciudades y villas andaluzas, en los convulsivos acontecimientos políticos de la minoría de Alfonso XI en Laureano RODRíGUEZ LiáÑEz y Ana María ANASAGASTi VALDERRAma, Niebla, Huelva y Gibraleón en las hermandades concejiles andaluzas de la Baja Edad Media, "Actas del VII Congreso de Profesores-Investigadores, Hespérides", Motril (Granada), 1988, pp. 137-167.
} 
Sin embargo, tan pronto como dió comienzo el reinado efectivo de Alfonso XI, el monarca intentó imponer una política de equilibrio entre las demandas de las ciudades y los intereses económicos de los hebreos, muy castigados durante el tiempo de su tutoría, lo que había hundido a la comunidad judía castellana casi en la ruina, por lo que habían sido muchos los hebreos que habían buscado la protección de la jurisdicción señorial, según se observa, con absoluta claridad, en las resoluciones tomadas por las Cortes de Valladolid, del 12 de diciembre de $1325^{76}$ y del 15 de febrero de 1326, relativas, estas últimas, a los vasallos de la Iglesia ${ }^{77}$.

Por entonces, el infante don Juan Manuel era una figura clave en la política castellana, no sólo en la corte, sino en su doble cometido de Adelantado Mayor de la Frontera y Adelantado Mayor de Murcia ${ }^{78}$, posición que culminaría con el matrimonio, el 28 de noviembre de 1325 , en Valladolid, entre Alfonso XI y su hija doña Constanza, cuya consumación quedó aplazada hasta 1329, por la corta edad de la novia. En junio o julio de 1326, el Adelantado de la Frontera obtuvo una gran victoria contra los granadinos, en las proximidades de Antequera. Sin embargo, muy pronto, Alfonso XI rompería su alianza con don Juan Manuel, cuando, tras repudiar a doña Constanza, contrajo matrimonio con María de Portugal, hija de Alfonso IV de Portugal, por lo que don Juan Manuel, desairado, se desnaturó de Alfonso XI y buscó la alianza con su suegro, Jaime II de Aragón, declarándose en rebeldía contra el rey castellano.

Entre julio y agosto de 1327, Alfonso XI protagonizó su primera y muy fructífera campaña contra el emirato nazarí de Granada, conquistando Olvera, Pruna, Ayamonte y Torre Alhaquime.

Mientras, la rebeldía de don Juan Manuel había hecho necesario el desplazamiento de tropas castellanas a la frontera aragonesa, por lo que uno de los validos del rey, Garcilaso de la Vega, murió asesinado en Soria, mientras se encontraba al frente de las tropas castellanas.

\footnotetext{
${ }^{76}$ Cortes, I, p. 378 s.- Fritz BAER, Die juden im christlichen Spanien, cit., doc. 149, p. 141.

${ }^{77}$ Cortes, I, p. 398. - Fritz BAER, Die juden im christlichen Spanien, cit., doc. 149, p. 141.

${ }^{78}$ Rogelio PÉREZ Bustamante, El gobierno y la administración de los reinos de la corona de Castilla (1230-1474), cit., II, p. 305: Don Juan Manuel ostentó ambos oficios, el de Adelantado Mayor de la Frontera y Adelantado Mayor de Murcia conjuntamente, en tres periodos distintos: 1322-1325, 1330-1336 y 1343-1347.- Diego ORTIZ DE ZÚÑIGA, Anales de Sevilla, cit., 2, año, 1396, cap. 5, p. 256, dice que fue Adelantado Mayor de la Frontera en 1306 y en 1325, además, Adelantado Mayor de Murcia.
} 
Por su parte, el otro valido de Alfonso XI, Alvar Núñez de Osorio, conde de Trastámara, se pasó al bando de don Juan Manuel, por lo que Alfonso XI hubo de ordenar su ejecución.

Una vez muertos ambos privados, muy pronto desaparecería de la escena política castellana un tercer hombre, que igualmente gozaba de la confianza regia, por lo que todos lo reconocían como uno de los favoritos del joven monarca: el judío sevillano don Yuçaf de Ecija. Pero, hagamos un poco de historia. El 12 de abril de 1327, en Madrid, el infante don Felipe dictó su testamento, en el que, entre otras cosas, reconocía las deudas que había contraído con don Yuçaf de Ecija, personaje al que Alfonso XI, una vez alcanzada la mayoría de edad, había hecho, por recomendación de su tío el infante don Felipe, almojarife mayor y miembro de su consejo, cargos que desempeñó hasta que, en el verano de 1328, ante las presiones de las Cortes de Madrid, Alfonso XI le privó de ellos. De todas maneras, en 1329, aparece de nuevo como almojarife mayor, aunque, ya por entonces, parece que empezó a ser reemplazado por su más directo rival, don Semuel aben Huacar, físico del monarca, quien habría de sustituirlo en la privanza regia, lo cual no impidió que don Yuçaf continuara siendo un personaje de primer orden en todo lo relativo a la política financiera de la monarquía castella$\mathrm{na}^{79}$.

Dentro de este contexto, debemos entender el hecho de que, el 9 de agosto de 1329, en las Cortes de Madrid, Alfonso XI accediera a algunas de las peticiones de los procuradores, en contra de los judíos, aunque no aceptase que fueran apartados de sus funciones financieras ${ }^{80}$.

Por fin, en 1330, don Juan Manuel volvió a la merced real, tras pedir perdón a Alfonso $\mathrm{XI}^{81}$.

\footnotetext{
${ }^{79}$ Fritz BAER, Die juden im christlichen Spanien, cit., doc. 150, p. 142-144.- Antonio Ballesteros, Don Yuçaf de Ecija, "Sefarad", VI (1946), pp. 253-287, recoge muchos datos e interesantes noticias en esta biografía del personaje.

${ }^{80}$ Cortes, I, pp. 415 s., 418 s., 421 s., 437.- Fritz BAER, Die juden im christlichen Spanien, cit., doc. 153, pp. 151-152.

${ }^{81} \mathrm{El}$ reinado de Alfonso XI, por lo que hace al ámbito andaluz, puede seguirse a través de Manuel García FernándeZ, Andalucía en tiempos de Alfonso XI, Sevilla, 1987.- Regesto documental andaluz de Alfonso XI, "Historia. Instituciones. Documentos", 15 (1988). pp. 1125. - Andalucia: Guerra y frontera (1312-1350), Sevilla, 1990.- Este mismo autor también ha aportado algunas noticias, en concreto, sobre el concejo de Niebla, durante estos años: Breves notas sobre el concejo de Niebla en tiempos de Alfonso XI: 1312-1350, "Huelva en su Historia", 1 (1986), pp. 171-181.
} 
Si la situación política, tanto en el interior como en el exterior, era comprometida, lo mismo ocurría, como es lógico, con la economía del reino, según puede apreciarse por los problemas que afectaban a la hacienda del concejo de Niebla, cada vez más deteriorada.

En 1325, las Cortes de Valladolid habían concedido a Alfonso XI, una vez alcanzada la mayoría de edad, cinco servicios y una moneda, que empezaron a recaudarse a principios de $1326^{82}$. Tan importantes recursos económicos harían posible no sólo la expedición contra Antequera, protagonizada, en 1326, por el infante don Juan Manuel, por entonces Adelantado Mayor de la Frontera, sino la conquista de Olvera y otras plazas fronterizas, como hemos dicho, en 1327, por el mismo Alfonso $\mathrm{XI}^{83}$.

Tal vez, la obligación que tenía Niebla, como concejo de realengo, de contribuir en estos servicios, así como el deterioro de su hacienda municipal, expliquen el hecho de que, el 26 de octubre de 1326, en Sevilla, los procuradores de Niebla otorgaran una carta de obligación, por valor de 30.000 maravedíes, a Alfonso Pérez, despensero del infante don Juan Manuel, quien, posiblemente, sería el encargado de recaudar estos impuestos, en el reino de Sevilla, por delegación del Adelantado Mayor de la Frontera ${ }^{84}$.

De la misma manera, el 3 de diciembre de 1327, en Sevilla, los procuradores de Niebla, Per Alfonso de Peñalosa, alcaide de su alcázar, alcalde y alguacil mayor de Niebla, junto con el vecino Martín Esteban, admiten que deben 40.000 maravedíes a don Alvar Núñez de Osorio, conde de Trastámara, mayordomo mayor y justicia mayor del rey, quien ya contaba con rentas en Moguer y que ese mismo año había intercedido ante Alfonso XI para que no tomase represalias contra los vecinos de Niebla, que se habían levantado contra el alcaide Ruy Fernández de Gibraleón, episodio al que ya nos referimos anteriormente. Ese mismo día, los personeros de Niebla se comprometieron a pagar estos 40.000 maravedíes al almojarife

\footnotetext{
p. 68.

${ }^{82}$ Miguel Ángel Ladero QueSAdA, Fiscalidad y poder real en Castilla (1252-1369), cit.,

${ }^{83}$ Manuel GaRCía FERNÁNDEZ, Andalucía: Guerra y frontera (1312-1350), p. 168.

${ }^{84}$ Miguel Ángel LADERo QueSADA, Niebla, de reino a condado, cit., p. 44, nota 90 , documento en el ADMS, Leg. 345.- Fritz BAER, Die juden im christlichen Spanien, cit., doc. 146, pp. 139-140, además de en su despensero mayor, don Juan Manuel, tenía depositada toda su confianza en algunos judíos, según aparece en gran parte de su documentación, incluidos sus sucesivos testamentos.
} 
judío de don Alvar Núñez de Osorio, don Yuda aben Iabar o a quien el conde ordenara ${ }^{85}$.

Por lo que sabemos, durante los años finales de la minoría de Alfonso XI, don Alvar Núñez de Osorio se había comportado como el auténtico señor de Niebla, habiéndose incautado de sus propios y arrebatando a la villa, incluso, su libro del repartimiento y otros privilegios ${ }^{86}$.

Afortunadamente para Niebla, por el momento, pudo conjurar el peligro de pasar a manos de un señor, ya que, como es sabido, muy pronto, don Alvar Núñez de Osorio, pagaría con la vida su traición a Alfonso XI, al haber tomado partido, esta vez también él, por el infante don Juan Manuel, lo que provocaría el paso a un discreto segundo plano de la esfera político-financiera castellana de su protegido don Yuçaf de Écija, hasta que las aguas volvieron a su cauce, cuando don Juan Manuel obtuvo el perdón real en $1330^{87}$.

Fue así como el 13 de diciembre de 1327, Alfonso XI cedía a Niebla los almojarifazgos de sus aldeas, que debían emplearse en el mantenimiento de su castillo, en recompensa a su contribución a la campaña de Olvera,

\footnotetext{
${ }^{85}$ Miguel Ángel LADERo QueSADA, Niebla, de reino a condado, cit., pp. 44-45, nota 91 , documento en el ADMS, Leg. 345.- Isabel MONTES ROMERO-CAMACHO, Notas para el estudio de la judería sevillana en la baja Edad Media (1248-1391), en "Historia. Instituciones. Documentos", 10 (1982), pp. 261-262 y 275, es posible que se trate de don Yudá aben Xabad, documentado, por esos años, como almojarife de Sevilla y recaudador de diezmos, quien también es probable que estuviese relacionado familiarmente con don Yuçaf de Ecija, cuyo nombre completo era raby Yuçaf el Levi aben Xabad, hijo de don Frayme y nieto de don Çag el Levi aben Xabad (Fritz BAER, Die juden im christlichen Spanien, cit., doc. 157, pp. 153155)

${ }^{86}$ María Luisa PARDo Rodríguez, Huelva y Gibraleón. Documentos para su historia (12811495). Huelva, 1980 , p. 78, según un documento fechado en 1332, citado por Manuel GONZÁLEZ JIMÉNEZ, Diplomatario andaluz de Alfonso X, cit. p. LXXIX, nota 38.

${ }^{87}$ Fritz BAER, Die juden im christlichen Spanien, cit., doc. 150, pp. 142-144, doc. 157, pp. 153-155, doc. 167, pp. 163-164.- José AMADOR DE LOS RíOS, Historia social, política religiosa de los judios de España y Portugal cit. pp 340-341 - Antonio BALLESTEROS, Don Juçaf de Écija, cit., pp. 252-287.- Acerca de la historia de los judíos castellanos y sus relaciones con la corona, durante el reinado de Alfonso XI, contamos con muchos e importantes trabajos de quien, tal vez, fuera el mejor conocedor de este reinado: Salvador de Moxó, entre otros Los judios castellanos en la primera mitad del siglo XIV, "Actas del Simposio 'Toledo Judaíco'", Toledo, 1972; IDEM, La sociedad política castellana en la época de Alfonso XI, "Cuadernos de Historia", 6 (1975), pp. 187-326, IDEM, Los judios castellanos en el reinado de Alfonso XI, "Sefarad", XXXV (1975), pp. 131-150 y XXXVI (1976), pp. 37-120 (Documentos).
} 
cesión que le fue confirmada por el monarca el 15 de diciembre de 1328, sobre Moguer ${ }^{88}$.

Sin embargo, no sería hasta el 24 de mayo de 1329, en Madrid, cuando, en atención a los ruegos que, en nombre de Niebla, le transmitiera su procurador Pedro Núñez de Guzmán, el monarca reintegró plenamente al concejo de Niebla "los propios que vos avedes de los almojarifazgos de las aldeas", según siempre los disfrutó hasta que "vos los embargó el traidor Alvar Núñez...", a excepción de los correspondientes a Moguer, que se reservaba, en beneficio de la hacienda regia, durante seis años ${ }^{89}$. De igual manera, ese mismo día, Alfonso XI, también a petición de Pedro Núñez de Guzmán, confirmaba todos los privilegios de Niebla ${ }^{90}$. Tal vez, también fuera este personaje el encargado, por orden Alfonso XI, de implantar, en el concejo de Niebla, el sistema de regimiento, que, desde 1327, el monarca ya había mandado establecer en Sevilla, aunque hasta 1351 no tenemos noticias ciertas de su funcionamiento regular en el municipio ilipense ${ }^{91}$.

Don Pedro Núñez de Guzmán pertenecía a una de las principales familias de hidalgos, afincadas en Niebla desde el mismo siglo XIII, entre cuyos miembros alcanzó una posición muy destacada este personaje, vasallo de Alfonso XI, que llegó a ser, al mismo tiempo, alcaide, alcalde mayor y alguacil mayor de la villa, así como, según hemos visto, su mandadero ante la corte de Alfonso XI. También, en 1330 y como recompensa a su fidelidad, fue beneficiado por el rey, de por vida, entre otras cosas, con las rentas que pertenecían a la corona en Villalva, aldea de Niebla ${ }^{92}$. Su hija,

\footnotetext{
${ }^{88}$ Miguel Ángel LADERO QUESADA, Niebla, de reino a condado, cit., p. 45, nota 92 y Fiscalidad y poder real en Castilla (1252-1369), cit., p. 147, nota 73, documentos en el ADMS, Legs. 742 y 743.

${ }^{89}$ Miguel Ángel LAdero QueSADA, Niebla, de reino a condado, cit., p. 45 , nota 94, documento en el ADMS, Legs. 345 y 742.

${ }^{90}$ Miguel Ángel LADERo QueSAda, Niebla, de reino a condado, cit., p. 45, nota 94, documento en el ADMS, Legs. 345 y 742

${ }^{91}$ Miguel Ángel LADERO QUeSADA, Niebla, de reino a condado, cit., pp. 59-60 y Rafael SÁNCHEZ SAUS, Caracterización de la nobleza medieval en el área onubense, cit., pp. 46-47.

${ }^{92}$ Rafael SÁNCHEZ SAUS, Caracterización de la nobleza medieval en el área onubense, cit., pp. 46-47, ha planteado la posibilidad de que se trate de su homónimo, don Pedro Núñez de Guzmán, ricohombre sevillano, casado con doña Juana Ponce de León y padre de doña Leonor de Guzmán, favorita de Alfonso XI y fundadora de la dinastía Trastámara. Sin embargo, a la vista de la documentación estudiada, nos inclinamos más por seguir su opinión anterior, recogida en su extraordinaria obra sobre la nobleza sevillana, donde se identifica, por una parte, a doña Leonor de Guzmán, la amante de Alfonso XI (Linajes sevillanos medievales, Sevilla, 1991, tomo I, p. 110 , reseñas $\mathrm{n}^{\circ} \mathrm{s} 12$ y 15 y t. II, p. 368, árbol genealógico $\mathrm{n}^{\circ} \mathrm{XXVI-A)} \mathrm{y,} \mathrm{por}$
} 
Leonor Pérez de Guzmán, como veremos, casó con otro criado de Alfonso XI, Francisco Fernández de Sevilla, que llegó a ser escribano mayor del concejo sevillano, siendo ambos los fundadores del futuro linaje de Fuentes, radicado en la ciudad a partir de entonces ${ }^{93}$.

De todas maneras, la orden real no debió cumplirse totalmente, ya que, en 1331, Alfonso XI volvía a ordenar la devolución de sus propios a Niebla, esta vez a excepción de Villalva, que, como Moguer, también pensaba ceder en señorío, como parece demostrar el hecho de que, según hemos dicho, subrogara sus rentas en favor de don Pedro Núñez de Guzmán, así como que, ya en marzo de 1331, tal vez por muerte del primer beneficiario, fuese su hija, doña Leonor Pérez de Guzmán, quien disfrutase las rentas reales de Villalva, que, según sabemos, le fueron cedidas a su padre sólo a título vitalicio ${ }^{94}$.

Algo similar puede decirse de la renta del almotacenazgo que en Niebla, al igual que en Sevilla, también formaba parte de sus propios $^{95}$.

Pero, todo ello no pudo evitar el progresivo e imparable empobrecimiento del concejo de Niebla, a pesar de algunos intentos por parte de Alfonso XI para remediar, temporalmente, la situación, como cuando, el 25 de junio de 1325, desde Illescas, en atención a que los vecinos de Niebla "son muy pobres y la villa mucho yerma", dió permiso al concejo para que

otra, a doña Leonor Pérez de Guzmán, hija de nuestro don Pedro Núñez de Guzmán, perteneciente a la rama de los Guzmanes, señores de Orgaz, y marido de doña Aldonza de Toledo (Linajes sevillanos medievales, cit., tomo I, pp. 112-113, reseñas $\mathrm{n}^{\circ} \mathrm{s} 1$ y 29 y t. II, $\mathrm{p}$. 369, árbol genealógico $n^{\circ}$ XXVI-B).

${ }^{93}$ Diego OrTIZ DE ZÚÑIGA, Anales de Sevilla, cit., 2, pp. 89, 90, 184, 192, 394, 410.Manuel GARCÍA FERNÁNDEZ, El reino de Sevilla en tiempos de Alfonso XI (1312-1350), cit., p. 285.- Rafael SÁNCHEZ SAUS, Linajes sevillanos medievales, cit., reseña de Francisco Fernández de Sevilla en Linaje de Fuentes, tomo I, pp. 102-103, reseña n I y tomo II, p. 366, árbol genealógico $\mathrm{n}^{\circ}$ XXXIV.

${ }^{94}$ Miguel Ángel LADERO QueSADA, Niebla, de reino a condado, p. 45, nota 95, documento en el ADMS, Leg. 743.- Rafael SÁNCHEZ SAUS, Linajes sevillanos medievales, tomo I, pp. 112 113 , reseñas $\mathrm{n}^{\circ} \mathrm{s} 1$ y 29 y t. II, p. 369, árbol genealógico $\mathrm{n}^{\circ} \mathrm{XXVI-B)}$ y Caracterización de la nobleza medieval en el área onubense, cit., p. 47.

${ }^{95}$ Miguel Ángel LADERO QUESADA, Niebla, de reino a condado, cit., p. 45, nota 96, documento en el ADMS, Legs. 345 y 743, el 6 de noviembre de 1332, en Sevilla, Verdugo de Arévalo, vecino de esta ciudad y antiguo alcalde de Niebla, reclamaba a Benito Arias, vecino de Niebla y arrendador de la renta su almotacenazgo, el dinero que le adeudaba del período de su alcaldía.- Miguel Ángel LADERo QueSADA, Los "propios" de Sevilla (1486-1502), cit., pp. 325 ss. 
edificase un lagar para cera, dejando a salvo, desde luego, los derechos pertenecientes al almojarifazgo real ${ }^{96}$.

De todas maneras y a pesar de los múltiples intentos de demostrar su buena voluntad por parte de la corona, los tiempos que corrían no eran, ni mucho menos, los más propicios para que un concejo como Niebla pudiese salvaguardar su condición realenga, sobre todo porque Alfonso XI necesitaba mucho dinero para poder hacer frente a los muy numerosos gastos de la hacienda real, acrecentados por el enorme coste de la campaña de Algeciras.

Por ello, no dudó en detraer un nuevo impuesto para la hacienda regia, como era el de la alcabala que, por lo que sabemos, ya beneficiaba a la corona, al menos en Andalucía y Murcia, desde $1333^{97}$. Como venía siendo normal, también esta nueva exacción regia se dejó sentir en el empobrecido concejo realengo de Niebla.

Así, el 7 de junio de 1338, en Niebla, algunos vecinos, entre ellos su alcalde, Pedro Fernández, y su mayordomo, Martín Esteban, así como, tal vez, el alcaide de su fortaleza, el escudero Pedro Yáñez, y Pedro Pérez Cendeño, en nombre del concejo de Niebla, reconocen que deben al judío don Çag albén Çadaq (cuyo nombre también aparece escrito como Zag Aben Zadaq / Zag Aben Zodoqui), vecino de la judería de Sevilla, dos mil maravedíes de moneda blanca, contados a diez dineros el maravedí, "por abenençia que el dicho conçeio fizo conbusco por razón del alcauala quel dicho conçeio de Niebla tomó desta dicha villa de Niebla el mes de la feria deste anno...". Para ello tendrían de plazo hasta el 31 de julio siguiente, so pena de cinco maravedíes por cada día que pasara de este aplazamiento. Si no lo hicieran así, el concejo respondería de su deuda y, en su caso, de la pena que se le impusiera por no cumplir el pago en el plazo establecido, "en

\footnotetext{
${ }^{96}$ Miguel Ángel LADERO QueSADA, Niebla, de reino a condado, cit., p. 46, nota 97, documento en el ADMS, Legs. 345 y 743.- IDEM, Fiscalidad y poder real en Castilla (12521369), cit., pp. 140-155, entre otras muchas rentas y derechos, correspondían al almojarifazgo real la renta o censo de algunos edificios, pertenecientes a la corona, que se utilizaban para diversos usos mercantiles o artesanales, entre los que se podría contar la fabricación de cera.

${ }^{97}$ Diego ORTIZ DE ZÚNígA, Anales de Sevilla, cit., 2, 1336, p. 90, se refiere a la nueva imposición de la alcabala, que iba en menoscabo de los propios de Sevilla.- Miguel Ángel LADERO QUESADA, Fiscalidad y poder real en Castilla (1252-1369), cit., pp. 175-190.- Manuel GARCÍA FERNÁNDEZ, Andalucía: Guerra y frontera (1313-1350), cit., pp. 169-174.
} 
la çibdat de Seuilla a vsso e a costunbre de alcauala de nuestro sennor el rey"98.

Según podemos deducir, a vuelapluma, el documento es extraordinariamente interesante, pues, a pesar de su concisión, nos da numerosas noticias no sólo relativas al concejo de Niebla, sino a realidad sevillana y andaluza en estos años de plena ebullición, en los que Alfonso XI se disponía a luchar contra granadinos y benimerines, con el fin de concluir la secular guerra del Estrecho $0^{99}$. De esta manera, además de pacificar internamente el reino, para lo que, como hemos dicho, intentó atraerse a los nobles rebeldes, especialmente a don Juan Manuel, necesitaba firmar la paz con vecinos tan poderosos como Pedro IV de Aragón y su suegro, Alfonso IV de Portugal, lo que consiguió en octubre de 1338, con lo que lograría asegurar no sólo las fronteras castellanas, sino la participación de estos dos importantes reinos peninsulares en la batalla del Estrecho ${ }^{100}$.

En primer lugar, debemos señalar que, a pesar de todas las dificultades y amenazas de señorialización que había tenido que soportar, en 1338, Niebla seguía siendo un concejo de realengo, según se deduce de este acuerdo concluido entre sus regidores y el judío sevillano don Zag aben Zadaq $^{101}$.

Igualmente, podemos constatar, sin ningún género de dudas, que, como hemos dicho, por estos años, la hacienda real cobraba, en su propio beneficio y de una forma regular, el nuevo impuesto de la alcabala, aunque, por entonces, sólo suponía el pequeño porcentaje del $3.33 \%$ de todas las compraventas $^{102}$.

${ }^{98}$ Documento III del Apéndice: AHN. Diversos. Concejos y ciudades (falta el número de leg.), puede ser el 75.- Cit. Miguel Ángel LADERo QUESADA, Niebla, de reino a condado, cit., p. 46, nota 99, según una copia existente en ADMS, Legs. 345 y 744.

${ }^{99}$ Manuel García Fernández, Andalucía: Guerra y frontera (1312-1350), cit., pp. 63-88.

${ }^{100}$ Manuel GARCía FERNÁNDEZ, Andalucía: Guerra y frontera (1312-1350), cit., pp. 61-62.

${ }^{101}$ Miguel Ángel LADERo QUESADA, Niebla, de reino a condado, cit., pp. 47-58 y Rafae SÁNCHEZ SAUS, Caracterización de la nobleza medieval en el área onubense, cit., pp. 47-48, destacan las múltiples amenazas señorializadoras que el concejo realengo Niebla hubo de soportar, entre 1329 y 1350 , por parte de vecinos tan poderosos como los señores de Gibraleón Palos, Moguer y Almonte, a los que se sumó la misma Iglesia de Sevilla, que ostentaba el señorío de Almonaster y Zalamea, presiones que, de momento, pudieron ser confabuladas gracias a la tenaz y casi heroica resistencia del concejo ilipense.

${ }^{102}$ Miguel Ángel Ladero Quesada, Fiscalidad y poder real en Castilla (1252-1369), cit. pp. 175-190: El rey ordenó cobrar "de cada maravedi dos meajas", por lo que, dado que el maravedí tenía 60 meajas, la imposición era del 3.33 por 100 , es decir un porcentaje muy pequeño, inferior, incluso, a la futura "veintena" ("del maravedí tres meajas" $=5$ por 100) que 
De esta manera, el concejo de Niebla se aviene a pagar a la corona dos mil maravedíes de moneda blanca, a razón de diez dineros el maravedí, en razón de las alcabalas que se habían recaudado en Niebla, durante el mes de la feria, de los que el concejo se había incautado, en su propio beneficio. Según sabemos, ya el 12 agosto de 1287, en Toro, Sancho IV había concedido feria a Niebla, aunque no fue hasta el reinado de Alfonso XI, concretamente el 12 de noviembre de 1336, en el real de sobre Lerma, cuando esta concesión de feria franca a Niebla, confirmada en 1348, adquiriría un carácter institucional. A partir de entonces, Niebla tendría, como Sevilla, treinta días de feria, entre el 16 de abril y el 15 de mayo, por lo que el documento, fechado el 7 de junio de 1338, nos habla de que la de ese año ya se había celebrado ${ }^{103}$.

De todo ello, podemos deducir, por una parte, la intención de la corona de favorecer a Niebla y de seguir defendiendo su condición realenga, lo que se desprende igualmente de la confirmación tardía de su feria en $1348, y$, por otra, la decadencia, también desde el punto de vista económico, en que se hallaba sumido el concejo, pues, incluso en el mes de la feria, sus alcabalas sólo se habían evaluado en dos mil maravedíes, lo que suponía un volumen de transacciones de sólo unos sesenta mil maravedíes, aproximadamente y, por si fuera poco, al beneficiar estas alcabalas a la hacienda regia, es posible que su cuantificación se hiciera a la alza.

En otro orden de cosas, debemos señalar que el cobro de la alcabala de todo el reino de Sevilla, se centralizaba en esta ciudad, cuyos alcaldes reales juzgarían cualquier delito, que pudiera generarse de su recaudación "en la çibdat de Seuilla a vsso e a costunbre de alcauala de nuestro sennor el rey".

Por otra parte, de nuevo, era un judío sevillano, don Zag Aben Zadaq, el que actuaba como recaudador de las alcabalas, en nombre del rey. Esto no resulta nada sorprendente, pues, como sabemos, los hebreos sevillanos siempre jugaron un papel de primer orden en el reino de Sevilla y al lado de los reyes, desde la misma conquista y repoblación de la ciudad.

\footnotetext{
ya empezó a cobrar Alfonso XI, al menos, en 1342, y, desde luego, a la posterior "alcabala del diezmo" ("del maravedí seys meajas" $=10$ por 100), que sería la habitual a partir de la dinastía Trastámara (Miguel Ángel LADERO QUESADA, La Hacienda real de Castilla en el siglo XV, La Laguna, 1973, pp. 61-89).

${ }^{103}$ Miguel Ángel LADERo QueSADA, Niebla, de reino a condado, cit., pp. 31-32, nota 45 y p. 41 , nota 79, documentos en el ADMS, Legs. 345, 744 y 745 .
} 
En este caso, se trata de la importante familia toledana de los Aben Zadoc, cuya rama sevillana fue fundada, nada menos, que por don Solomón ibn Zadok de Toledo, llamado en las fuentes de la época don Çulemán, que llegaría a ser, como almojarife mayor y mandadero real, uno de los personajes más influyentes de la corte de Alfonso X. Su hijo, don Çag Aben Zadoc, conocido como don Zag de la Maleha, al que ya nos hemos referido, heredó los cargos y riquezas de su padre, pero cayó en desgracia ante Alfonso X, que lo mandó ejecutar en $1279^{104}$. De todas maneras, parece ser que sus descendientes sevillanos, tras un tiempo de alejamiento, habían vuelto a recuperar el favor real, como puede demostrar el caso de este nuevo don Çag Aben Zadoc, alcabalero por Alfonso XI en Sevilla y, posiblemente, al igual que otros muchos judíos, prestaron importantes servicios a la corona en todo lo concerniente a la compleja infraestructura económica que era necesaria para la culminación de la conquista del Estrecho ${ }^{105}$.

El 1 de noviembre de 1338, el concejo dió en arriendo, por un período de ocho años, los almojarifazgos de las aldeas de su término ${ }^{106} \mathrm{y}$ el montazgo ${ }^{107}$, correspodientes ambos a sus rentas de propios $^{108}$. Los almojarifazgos fueron arrendados por 42.000 maravedíes y el montazgo por 8.000 maravedíes, es decir 1.000 maravedíes anuales, con la condición de que si no se recaudaban, por lo menos, 6.000 maravedíes cada año por los

\footnotetext{
${ }^{104}$ Son innumerables los datos que poseemos sobre estos personajes judíos sevillanos, que aparecen resumidos en Isabel MONTES ROMERO-CAMACHO, Notas para el estudio de la judería sevillana en la baja Edad Media (1248-1391), cit., pp. 259-260; El antijudaísmo o antisemitismo sevillano hacia la minoría hebrea, en "Segundos Encuentros Judaícos de Tudela", 1996, pp. 8588 y Mudéjares y judíos en la Sevilla del siglo XIII, en "Sevillla 1248, Congreso Internacional conmemorativo del 750 Aniversario de la conquista de Sevilla por Fernando III, Sevilla", noviembre 1998 (en prensa).- Igualmente, es muy interesante la interpretación dada por Manuel GONZÁLEZ JimÉnEZ, Alfonso X. 1252-1284, Palencia, 1993, pp. 125-131 y Alfonso $X$ y las minorias confesionales de mudéjares y judios, cit., pp. 76-78, que recoge, además, las aportaciones de Joseph F. O'Callaghan, El Rey Sabio. El reinado de Alfonso X de Castilla, Sevilla, 1996, pp. 284-298.

${ }^{105}$ José AMADOR DE LOS Ríos, Historia social, política y religiosa de los judios de España y Portugal, cit., pp. 342 ss.

${ }^{106}$ Eran Rociana, Bonares, Beas, Trigueros, El Cortijo de Pero Caro, La Torrecilla, La Palma y Villalva.

${ }^{107}$ Miguel Ángel LADERo QUESADA, Fiscalidad y poder real en Castilla (1252-1369), cit., pp. 126-130, el montazgo fue cobrado por muy diversos señores e instituciones, entre las que se contaban los concejos, hasta que, en 1343, Alfonso XI lo reservó para la hacienda regia, a causa de las grandes necesidades económicas generadas por la campaña de Algeciras.

${ }^{108}$ Miguel Ángel LAdero QUESADA, Niebla, de reino a condado, cit., p. 46, nota 98, documento en el ADMS, Leg. 345 y en el AGS, Medina Sidonia, c. 3, nº 29.
} 
almojarifazgos, el concejo de Niebla respondería de ese mínimo con su propia hacienda. En cuanto a los arrendadores de estas rentas, debemos destacar que eran muy numerosos, bien fuesen cristianos -0 , tal vez, conversos - o judíos. Algunos de ellos eran vecinos de Niebla, como Ferrant Pérez de Moguer o los judíos don Zag Aben Santiel ${ }^{109}$ o don Abraham Aromaes $^{110}$. Otros, estaban avecindados de Sevilla, bien fueran cristianos, como Domingo Martín de Aguilar o Francisco Fernández, escribano del concejo hispalense ${ }^{111}$ o judíos, caso de don David Aben Pex ${ }^{112}$, don Sisa Aben Aladeb, almojarife del señor de Gibraleón, don Juan Alfonso de la Cerda, o su hermano, don Mose Aben Aladeb ${ }^{113}$.

\footnotetext{
${ }^{109}$ Como sabemos, en la aljama judía de Niebla era normal, desde su fundación, la presencia de vecinos de origen portugués. Así, concretamente, el apellido de este linaje judío tal vez haga referencia a su posible procedencia de la isla portuguesa de Saltés, según se documenta, ya en el siglo XV, para otros judíos sevillanos (Isabel MONTES ROMERO-CAMACHO, Los judíos sevillanos (1391-1492). Del asalto a la expulsión. Datos para una prosopografía, en "Actas de las III Jornadas Hispano-Portuguesas de Historia Medieval: La Península Ibérica en la era de los descubrimientos, 1391-1492", Sevilla, 1997, pp. 173 y 254).

${ }^{110}$ Según hemos visto, miembros de este linaje judío pudieron establecerse en Niebla, quizá procedentes de Jerez, desde los mismos años de su repoblación, dedicándose, muchas veces, a asuntos relacionados con las finanzas concejiles.

I'Tal vez se trate de Francisco Fernández de Sevilla, criado de Alfonso XI y persona muy próxima al monarca. Desde el 19 de febrero de 1337, al menos, era escribano mayor del concejo de Sevilla, en lugar de Nicolás Pérez de Villafranca, por concesión de Alfonso XI. Contrajo matrimonio con Leonor Pérez de Guzmán, posiblemente hija de Pedro Núñez de Gúzmán quien, como es sabido, fue alcaide, alcalde y alguacil mayor de Niebla y miembro de uno de los linajes hidalgos, vecinos de la villa (Diego ORTIZ DE ZÚNIIGA, Anales de Sevilla, cit., 2, pp. 89, 90, 184, 192. 394, 410.- Rafael SÁNCHEZ SAUS, Linajes sevillanos medievales, cit., reseña de Francisco Fernández de Sevilla en Linaje de Fuentes, XXXIV, I), tomo I, pp. 102103). Ambos, como padres de Alfonso Fernández de Fuentes, fundador del mayorazgo de este nombre, fueron los progenitores del linaje de Fuentes, emparentado, ya en la segunda mitad del siglo XIV, con otras importantes familias de la oligarquía sevillana, como los Las Casas, Tesoreros Mayores de Andalucía, o los Marmolejo, uno de los más representativos linajes conversos sevillanos, en ascenso permanente, desde mitad del siglo XIV (Rafael SÁNCHEZ SAUS, Linajes sevillanos medievales, cit, Linaje de Las Casas, XXI, tomo I, pp. 65-71, tomo II, p. 356, Linaje de Fuentes, XXXIV, tomo I, pp. 101-104, tomo II, p. 366, Linaje de Marmolejo, XLVII, tomo I, pp. 157-163, tomo II, pp. 382-383).

1"2Parece tratarse de un miembro de la conocida familia judía sevillana de los Aben Yex, uno de cuyos personajes más destacados sería don Mayr Aben Yex, documentado como almojarife de Sevilla y como arrendador de sus rentas de propios en la segunda mitad del siglo XIV (Isabel MONTES ROMERO-CAMACHO, Notas para el estudio de la judería sevillana en la baja Edad Media (1248-1391), cit., pp. 263 y 275).

${ }^{113}$ Son muy numerosos los miembros de este linaje judío sevillano -cuyo apellido aparece como Aben Aladab, Aladeb, Alabeb, Ataheb... - documentados por estas fechas, como don Judá Aben Ataheb, arrendador del almojarifazgo de Sevilla, entre 1314-1315, don Samuel Aben Ataheb, almojarife de Sevilla en 1327, don Çag Aben Aladab, arrendador de las rentas de propios de Sevilla, en 1368, don Çulemán Aben Ataheb, marido de doña Çibdona, padre de Çag Huérfano y hermano de don Judá Aben Ataheb, almojarife de Sevilla entre 1368-1369, don
} 
Sea como fuere, el tiempo demostró que las cautelas de los arrendadores no eran vanas, debido al enorme deterioro que el concejo realengo de Niebla seguía sufriendo en cuanto a sus bienes y rentas de propios, entre otras cosas, por la cada vez más fuerte e imparable presión señorial, que la corona toleraba, en parte por las imperiosas necesidades, políticas y económicas, que le suponían, entre otras cosas, la guerra en la frontera y la amenaza benimerí. Así, cuando en 1342, le fueron enajenadas a Niebla sus aldeas de Beas y Trigueros, para incorporarlas al señorío de Gibraleón, cuyo titular era don Juan Alfonso de la Cerda, éste obtuvo un alto beneficio, ya que no sólo ampliaba su señorío con las dos aldeas, sino que, según la concordia que estableció con Niebla, el 6 de marzo de 1343, en el real sobre Algeciras, recibía amplios derechos de intervención en todo lo relativo a los intercambios comerciales y a la utilización de sus extensas tierras de pasto y monte en el término de Niebla, mientras, en contrapartida, el concejo de Niebla sólo obtuvo algo, poco, más que su compromiso a pagar los 16.000 maravedíes que restaban de dar a los arrendadores que, como hemos dicho, habían tomado en renta, por ocho años, los almojarifazgos y el montazgo de Niebla, en $1338^{114}$. A pesar de todo, hasta el 16 de agosto de 1348, en Niebla, Pedro Fernández, hijo de Ferrant Pérez de Moguer, no otorgó carta de finiquito, en la parte correspondiente a su padre ${ }^{115}$.

En 1338, Niebla pudo recuperar su jurisdicción sobre Villalva del Alcor, a costa de un gran esfuerzo económico, pues su señor, don Alvar Pérez de Guzmán recibió, a cambio, 60.000 maravedíes, de los cuales 30.000 maravedíes debió pagar la corona y otros 30.000 maravedíes Niebla. Así, el 19 de marzo de 1339, en Sevilla, don Alvar Pérez de Guzmán, alcalde mayor de Sevilla, otorgó carta de pago de los 30.000 maravedíes que le correspondían al concejo de Niebla, que los había pedido prestado al trapero sevillano Nicolás Pérez de Villafranca, endeudamiento que hacía aún más comprometida la débil situación fiscal de Niebla, sometida, como todos

\footnotetext{
Yuçaf Aben Alabeb ó Ataheb, juez viejo de la aljama de Sevilla, en 1369... (Isabel MoNTES ROMERO-CAMACHO, Notas para el estudio de la judería sevillana en la baja Edad Media (12481391), cit., pp. 251-277).

${ }^{114}$ Miguel Ángel LADERo Quesada, Niebla, de reino a condado, cit., p. 56, nota 123, documento en el ADMS, Leg. 345.

${ }^{115}$ Miguel Ángel LADERo QUESADA, Niebla, de reino a condado, cit., p. 46, nota 98 documento en el ADMS, Leg. 345 y en el AGS, Medina Sidonia, c. 3, n 29.
} 
los concejos realengos a una presión extrema, por parte de la fiscalidad real $^{116}$.

Este Nicolás Pérez de Villafranca, "El Mozo", era hijo de Nicolás Pérez de Villafranca, "El Viejo", y, como él, escribano mayor del concejo hispalense. Su padre ya aparece como escribano mayor de Sevilla en 1283 y en 1293 continuaba ejerciendo este oficio y era, a la vez, secretario de Sancho IV, quien lo puso al frente de las milicias sevillanas que lograron romper el cerco de Tarifa ${ }^{117}$.

Sin embargo, muy pronto, Niebla volvería a sufrir un nuevo cercenamiento en su término jurisdiccional, ya que el 2 de diciembre de 1342, en el real sobre Algeciras, Alfonso XI, sin duda por los graves aprietos económicos a que se veía sometida la hacienda regia, a causa del cerco de la ciudad, concedía la jurisdicción de Beas y Trigueros, aldeas de Niebla, a don Juan Alfonso de la Cerda, señor de Gibraleón ${ }^{118}$. Por fortuna para Niebla, a la muerte sin herederos del señor de Gibraleón, en 1346, pudo recuperar la jurisdicción sobre sus antiguas aldeas, cuando sus albaceas las subastaron por 100.000 maravedíes, que debía recibir doña María de Luna, viuda de don Juan Alfonso de la Cerda, de los cuales, como en el caso de Villalva, la mitad, 50.000 maravedíes serían pagados por la corona y los otros 50.000 maravedíes por el concejo de Niebla, según se deduce de la carta de pago librada por los albaceas del difunto, en Niebla, el 27 de mayo de $1346^{119}$.

El 20 de julio de 1345, en la Corte del Adelantado ${ }^{120}$, el concejo

\footnotetext{
${ }^{116}$ Miguel Ángel LAdero QueSADA, Niebla, de reino a condado, cit., p. 52, nota 113 , documento en el ADMS, Legs. 345 y 744.

${ }^{117}$ Diego OrTIZ DE ZúNĩga, Anales de Sevilla, cit., 2, pp. 282, 410.- Rafael SánChEZ SAUS, Linajes sevillanos medievales, cit., reseña del Linaje Villafranca, $\mathrm{n}^{\circ}$ LXXXI, tomo I, pp. 321322 y tomo II, p. 420, Nicolás Pérez de Villafranca, "el Viejo", aparece en la p. 321, nota 1) al árbol genealógico, y su hijo, Nicolás Pérez de Villafranca, "el Mozo", en la p. 321, nota 2).

${ }^{118}$ Miguel Ángel LADERO QUeSADA, Niebla, de reino a condado, cit., p. 53, nota 115, documento en el ADMS, Leg. 727.

${ }^{119}$ Miguel Ángel LaDERo QUESADA, Niebla, de reino a condado, cit., p. 53, nota 116, documento en el ADMS, Legs. 345, 347, 744 y 745.

${ }^{120}$ Según algunos antiguos historiadores podría tratarse de don Pedro Fernández de Castro, llamado "el de la guerra", que había sido pertiguero mayor de la Iglesia de Santiago y adelantado mayor de Galicia, quien, desde 1339, era Adelantado Mayor de Andalucía, por Alfonso XI, y que, una vez establecido en Sevilla, había contraído matrimonio con doña Isabel Ponce de León, que pertenecía a este importante linaje sevillano, siendo padres de doña Juana de Castro, tenida por reina de Castilla, al ser una de las mujeres de Pedro I y madre de don Juan de Castilla (Diego OrTIZ DE ZúN̄igA, Anales de Sevilla, 2, año, 1396, cap. 5, pp. 256-
} 
de Niebla volvió a contraer una nueva deuda. Esta vez recibió 9.000 maravedíes de Ferrán Martínez de Agüera, ome de nuestro señor el rey, cantidad de la que quedaron como fiadores cuatro vecinos de Niebla, dos de ellos judíos: don Abraham Arramaque y don Zag Santiel, a los que ya documentamos anteriormente, en 1338, como dos de los arrendadores, por un período de ocho años, de los almojarifazgos de las aldeas y del montazgo de Niebla, así como otros dos cristianos: Juan Bartolomé y Diego García $^{121}$.

Igualmente, en 1345, el almojarifazgo de Niebla fue arrendado por dos años, a contar desde 1350, siendo su importe de sólo 6.000 maravedíes, a los mismos arrendatarios del almojarifazgo de Murcia, que rentaba nada menos que 118.000 maravedíes, los judíos don Mayr y don David Aventuriel, hijos de don Çag, junto con don Mayr el Leví, hijo de don Yento el Leví, vecino de Alcaraz ${ }^{122}$. Tal vez, este arrendamiento conjunto del rico almojarifazgo de Murcia y el muy pobre de Niebla, pueda explicarse por el hecho de que, durante estos años, como sabemos, don Juan Manuel volvía a reunir, por tercera vez, la doble condición de de Adelantado Mayor de Murcia y de Adelantado Mayor de la Frontera ${ }^{123}$.

$$
* * *
$$

257.- Rafael SÁNCHEZ SAUS, Linajes sevillanos medievales, cit., I, p. 233, nº LXIII. Linaje de Ponce de León, reseña $\mathrm{n}^{\circ} 15$ y II, pp. 402-403). Sin embargo, otros autores establecen su cronología, como Adelantado Mayor de Andalucía, entre 1336 y 1342, por lo que, en 1345 , parece tratarse, nuevamente, del infante don Juan Manuel, que volvió a ostentar el cargo de Adelantado Mayor de la Frontera, junto con el de Adelantado Mayor de Murcia, por tercera vez, entre 1343-1347 (Rogelio PÉREZ BUSTAMANTE, El gobierno y la administración de los reinos de la corona de Castilla (1230-1474), cit., II, pp. 301 y 305).

${ }^{121}$ Miguel Ángel LADERO QUESADA, Niebla, de reino a condado, cit., p. 46, nota 100, documento en el ADMS, Leg. 345.

${ }^{122}$ Miguel Ángel LADERo QueSADA, Fiscalidad y poder real en Castilla (1252-1369), cit. p. 153, también fueron judíos los arrendatarios del almojarifazgo de Murcia en los años siguientes, ya en el reinado de Pedro I (1350-1369). Así, en 1352, el 75 por 100 de la renta fue arrendado por don Mayr, don Yuçaf y don Çuleiman Aventuriel y el 25 por 100 por don Yuçaf Axaques, escribano de don Samuel el Leví, almojarife mayor del rey, y don Hayn Aventuriel, de la misma familia que los anteriores, pues, tanto unos como otros, eran hijos de Çag y Mose Aventuriel. Ya en 1354, los arrendatarios del almojarifazgo murciano fueron los sevillanos don Yuçaf Abenhalas? y don Yuda Abenacacab?. (Es muy probable que la grafía de los apellidos esté deformada, al ser transcrita al romance, pero, sea como fuere, hay numerosos judíos sevillanos contemporáneos cuyo apellido y otras características, como su oficio, hacen que sea posible relacionarlos familiarmente con estos almojarifes: Isabel MONTES ROMERO-CAMACHO, Notas para el estudio de la judería sevillana en la baja Edad Media (1248-1391), cit., pp. 251277).

${ }^{123}$ Rogelio PÉREz BuStamante, El gobierno y la administración de los reinos de la corona de Castilla (1230-1474), cit., II, p. 305. 
Todavía, el 28 de agosto de 1366, en Sevilla, Ferrán Pérez de Villafranca, trapero de la calle de Francos, dió en préstamo al concejo de Niebla 22.000 maravedíes ${ }^{124}$. Este Fernán Pérez de Villafranca es posible que perteneciese a la misma familia que Nicolás Pérez de Villafranca, otro trapero que, como sabemos, también había realizado préstamos de dinero al concejo de Niebla, en 1338. Como él, estuvo muy bien situado en la política municipal sevillana, donde su carrera fue en ascenso hasta culminar en el reinado de Juan I, cuando, además de ser veinticuatro de Sevilla, ejerció el cargo de veedor de la guerra, contra Portugal y el duque de Lancaster, junto con Juan Martínez (de Medina), armador de la flota real, y Alonso Fernández del Marmolejo, mientras su pariente Guillén Alfonso de Villafranca (o del Bizcocho) era el encargado del abastecimiento de la armada, como tenedor de los hornos del bizcocho del Alcázar sevillano ${ }^{125}$, así como el de mayordomo de Sevilla, teniendo como lugarteniente a Micer Sologrús Bocanegra, entre 1388-1389 ${ }^{126}$. Sea como fuere, los Villafranca pueden considerarse como un linaje típico sevillano que, gracias a su función económica y a sus relaciones, muchas veces matrimoniales, con otras ricas e influyentes familias sevillanas, muchas veces de origen converso, como los Medina y los Marmolejo, lograron alcanzar, en el siglo XIV, un papel de primer orden en el concejo hispalense, al tiempo que formar parte de la oligarquía sevillana ${ }^{127}$.

\footnotetext{
${ }^{124}$ Miguel Ángel LADERo QueSADA, Niebla, de reino a condado, cit., pp. 46-47, nota 101, documento en el ADMS, sin numeración.

${ }^{125} \mathrm{La}$ importante actuación de estos personajes en tan complejo período de la historia castellana, por lo que hace al papel jugado por Sevilla, en Isabel MONTES ROMERO-CAMACHO, Protagonismo sevillano en las aspiraciones de Juan I de Castilla (1379-1390) al trono de Portugal, en "Actas de las IV Jornadas Luso-Espanholas de História Medieval", Porto, 1997 (en prensa).

${ }^{126}$ Francisco Collantes De TeRÁN Delorme, Inventario de los Papeles del Mayordomazgo del siglo XIV, Sevilla, 1968, 1386-1387, $\mathrm{n}^{\circ}$ s. 14 y 21; 1386-1396 (Castillos), nos 9 y 18 . Rafael SÁNCHEZ SAUS, Linajes sevillanos medievales, cit., tomo I, p. 322, Linaje Villafranca $n^{0}$ LXXXI, 19) reseña de Fernán Pérez de Villafranca y tomo II, p. 420.

${ }^{127}$ Rafael SÁNCHEZ SAUS, Linajes sevillanos medievales, cit., reseñas de los linajes Marmolejo, XLVII, tomo I, pp. 157-163 y tomo II, pp. 382-383, Medina, L, tomo I, pp. 172183 y tomo II, pp. 386-387 y Villafranca, LXXXI, tomo I, pp. 321-322 y tomo II, p. 420.
} 


\section{APÉNDICE DOCUMENTAL}

1294, febrero, 1. Tejada

Don Juan Fernández, adelantado mayor de Andalucía, ordena al concejo de Niebla que los judios no presten a más del "tres por quatro", según lo dispuesto por el rey.

B. Archivo Histórico Nacional (AHN), Diversos. Concejos y ciudades, leg. 75, n. $6^{1}$. Cit. Miguel Ángel LADERO QUESADA, Niebla, de reino a condado. Noticias sobre el Algarbe andaluz en la Baja Edad Media, Madrid, 1992, p. 29, nota 37, según una copia existente en ADMS.

B. Archivo de los Duques de Medina Sidonia (ADMS), Leg. 345

De mí don Johán Fernández, adelantado mayor de la frontera por el muy noble rey don Sancho e por el infante don Fernando su hijo primero heredero, a los alcaldes del rey en Niebla, salut como aquéllos para quien querría mucha buena ventura.

Los omes buenos del conceio de Niebla se me embiaron querellar y disen que ay algunos omes sus vezinos que sacaron dineros de judíos a logro, del postremero día de mayo primero que pasó acá y que el logro que dellos tienen es muy grant, en guisa que resciben gran danpno por que se podía tomar la villa, e pidiéronme, pues el rey tovo por bien e ordenó que en ningún lugar de su tierra no dé judío a christiano más de tres por quatro por los dineros que dél sacare, que mandase yo lo que toviese por derecho.

Porque vos mando de parte del rey y del infante don Ferrando y vos digo de la mía que non consintades que judío tome del christiano por los maravedís que dél sacó o sacare daquí adelante a más de tres por quatro, del postrimero día de mayo sobredicho acá, segunt dise la carta del rey que el consejo de Sevilla tiene sobre esta rasón, y non consintades que liebe otra pena maguer el christiano sea obligado en la carta a éste. E non fagades ende al. Si non, cuanto dapno y menoscavo recibiesen por mengua de lo que vos y abedes a fazer con derecho, de vuestras casas gelo mandaría entregar todo doblado. Et desto les mandé dar esta carta. Leída, dádgela. 
Dada en Tejada, primero día de febrero, era de mill y trescientos y treinta y dos años.

Yo Johán Martínez la fis por mandado de Pedro Ledo, alcalde del rey.Pedro Ledo.

1306, febrero, 6. Niebla

Acuerdo entre el concejo y los judios de Niebla sobre el pago de las deudas de los cristianos.

A. AHN, Diversos. Concejos y ciudades, carp. 3, n. 111 (I).

Cit. Miguel Ángel LADERo QUESADA, Niebla, de reino a condado. Noticias sobre el Algarbe andaluz en la Baja Edad Media, Madrid, 1992, pp. 29-30, nota 38, según una copia existente en ADMS.

B. Archivo de los Duques de Medina Sidonia (ADMS), Leg. 345

Sepan quantos esta carta vieren commo nos el conçeio de Niebla, veyendo las cartas de nuestro sennor el rey don Ferrando en que nos enbió dezir e mandar que sobre querellas quel aljama de los judíos de Niebla et don Yhude Abrauaniel (ilegible) se le enbiaron querellar que por razón que en la villa de Niebla que non auién alcalles que ellos non podién auer lo que les deuién para pagarle los sus pechos e los sus pedidos, e quel pedieran merçed que les diese quien gelo librasse, et por razón que Amado Díaz e Velasco Martínez, nuestros vezinos, le dixeran que eran omnes que lo sabrían fazer, que tenién por bien que lo librassen lo que deuién los christianos a los judíos, segunt las sus cartas del rey diçen, nos, queriendo hobedezer e conplir las cartas de nuestro sennor el rey e catando en commo el estado de la tierra era muy menguado e los vezinos muy pobres e muy endebdados e que podién seer derraygados, et entendiendo que es seruiçio de Dios e del rey nuestro sennor e pro de la tierra, por esta razón feziemos conpusiçión e postyura con don Çag Arramat e con don Fraym Alfandarí e con don Çuleymán Portugalés, por ellos e por el aljama de los de Niebla e moradores e del término assí commo aquuí dirá en esta carta:

[1] Que todos los christianos vezinos e moradores de la villa de Niebla e de su término que algo deuen a los judíos con cartas o con aplaçamientos, assí commo nuestro sennor el rey enbía mandar por sus cartas, que den luego la meatad; e si la non quissieren dar, que los lieuen ante los dichos Amado Díaz e Velasco Martínez o qual quier dellos que los ayna e los libren con fuero e con derecho, sin alongamiento ninguno. Et la otra meatad que la paguen el día de Sant Miguel de setiembre, éste primero que viene. 
[2] Et del tienpo que es pasado nin fasta el día de Sant Miguel el dicho plazo, que non ganen las depdas nin aya ay penas ningunas de las cartas nin de los aplazamientos.

[3] Et otrossí que ayan e libren todas las depdas que les deuen con cartas e con aplazamientos e con aluarás fechos dante que los plazos non son venidos, que los paguen luego e que puedan conplir su juyzio.

[4] Et otrossí nos obligamos nos los dichos don Çag e don Fraym e don Çuleymán por nos e por la dicha aljama e por los moradores, que si ellos e nos algo deuemos a los christianos o debda ayan contra nos, que estos dichos Amado Díaz e Velasco Martínez que los ayan convusco e lo libren e lo paguen assí commo es fuero e derecho e que cunplan su juyzio.

Et porque esto sea firme e estable e non venga en dupda, nos el dicho conçeio et nos don Çag Arromat e don Fraym Alfandarí e don Çuleymán los dichos judíos, por nos e por el aljama de los judíos e moradores de Niebla otorgamos de conplir e de auer por firme todo quanto esta carta diçe so pena de diez mill marauedíes desta moneda que agora anda. La qual carta fue fecha e otorgada e sin ninguna premia.

Et por lo conplir e tener, mandamos ende fazer dos cartas partidas por abc, amas de vn tenor, que tengamos nos el conçeio la vna firmada de uos don Çat Arramat e de uos don Fraym e de uos dom Çuleymán e de rabí Salomón en Abrayto; et la otra que tengades uos e el aljama, seellada con nuestro seello colgado, que fueron fechas e otorgadas domingo seys días de febrero, era de mill e ccc e quarenta e quatro annos. paguen luego.

Ay sobrescripto en dos lugares: el vno dize auer et el otro dize que les

Yo Ishaq ben Abramat testigo.- Yo Efraim ben Alfandari testigo.- Yo Suleimán ben Absalulán testigo.- Yo Salomón'.

Et yo, Martín Pérez, la escriuí por mandado del conçeio e de los dichos judíos.

\section{III}

1338, junio, 7. Niebla

Per Yáñez, escudero, Pedro Fernández, alcalde en Niebla, Martín Esteuan, mayordomo del concejo y Pedro Pérez Cendeño, vecinos todos de Niebla, se

\footnotetext{
'El texto está escrito en árabe con letras hebreas. Agradecemos la transcripción del texto realizada por el Dr. D. José Luis Lacave, del Instituto de Filología del CSIC (Madrid).
} 
comprometen a satisfacer a don Zag abén Zadaq, judio, vecino de la judería de Seuilla, los 2.000 mrs. en que fueron valoradas las alcabalas de la villa.

\begin{abstract}
A. AHN. Diversos. Concejos y ciudades (falta el número de leg.), puede ser el 75. Cit. Miguel Ángel LADERO QueSADA, Niebla, de reino a condado. Noticias sobre el Algarbe andaluz en la Baja Edad Media, Madrid, 1992, p. 46, nota 99, según una copia existente en ADMS.

B. Archivo de los Duques de Medina Sidonia (ADMS), Legs. 345 y 744.
\end{abstract}

Sepan quantos esta carta vieren commo yo Per Yánnez, escudero, et yo Pero Ferrández, alcalle en Niebla, et yo Martín Esteuan, mayordomo del conçeio desta dicha villa, et yo Pero Pérez Çendenno, vezinos que somos desta dicha villa de Niebla, nos todos quatro de mancomún e a boz de vno, e cada vno de nos por el todo, otorgamos que deuemos dar e pagar a vos don Çag albén Çadaq, judío, vezino de la judería de Seuilla, o a quien esta carta mostre por vos, dos mill mrs. de la moneda blanca que valen diez dineros el marauedí, que vos entramos manos e debdores e pagadores llanamientre sin ninguna condiçión, de uos los dar por el conçeio de Niebla que vos los auía de dar por abenençia que el dicho conçeio fizo conbusco por razón del alcauala quel dicho conçeio de Niebla tomó desta dicha villa de Niebla el mes de la feria deste anno. Et estos dichos dos mill mrs. vos deuemos nos pagar fasta el postrimero día del mes de jullio primero que verná, so pena de çinco mrs. cada día quantos días passaren después del plazo dicho en adelante. Et obligamos nos de uos responder por este debdo e por la pena, sy en ella cayéremos, en la çibdat de Seuilla a vsso e a costunbre de alcauala de nuestro sennor el rey. Et por lo conplir obligamos a nos e a todos nuestros bienes quantos oy día avemos e avremos daquí adelante.

Fecha la carta en Niebla, siete días de junio, era de mill e trezientos e setenta e seys annos.

Ay sobrescripto o diz por e o diz deste anno.

Yo Juan Bartolomé so testigo.- Yo maestre Johán so testigo.- Yo Diego Garçía, escriuano público por el rey en Niebla, so testigo.- Yo Pero ferrández, alcalle, so testigo.- Et yo Saluador Sánchez so testigo.- Yo Nicolás Garçía so testigo.- Yo Pero Pérez Çendenno so testigo.

Et yo Alfonso ferrández, escriuano público por el rey en Niebla, la fiz escriuir e mío sig-[RUBRICA]no y fiz e so testigo. 


\section{RÉSUMÉ}

Après la conquête de la ville de Niebla (1262), et comme il procédait à sa repopulation, Alphonse $\mathrm{X}$ se proposa d'eriger un grand conseil municipal en tête de l'Algarve andalou. Néanmoins, la Couronne castillane dût bientôt faire face à des circonstances défavorables, accentuées en Andalousie à cause des problèmes dérivés de la constitution d'une société de frontière.

Cette réalité se révéle clairement à propos du conseil municipale de Niebla, lequel, pendant l'étape d'appartenance au domaine royal (1262-1368), essaya d'opposer une forte résistence aux nombreux périls de seigneurialisation qui supporta, en finissant par succomber. Parmi d'autres raisons, on peut constater les énormes difficultés économiques auxquelles les juifs ne furent pas d'autrui, étant donné qu'ils arrivèrent à monopoliser la plupart des activités financières du Royaume de Séville pendant le premier siècle de la population d'Andalousie.

\section{SUMMARY}

When Alphonsus X conquered Niebla in 1262 and initiated the settlement of the area, Niebla became a royal town and the capital of the Andalusian Algarve. The problems that arose in Andalusia in the century that followed (1262-1368), particularly those that stemmed from the fact that it was a frontier ares, were especially evident in Niebla, where the town had to resist numerous attempts by the nobles who tried to wrest it from royal control. This resistance was finally overcome in 1368, mainly because of the enormous financial difficulties of the town council, which were created to no small extent by the Jews, who, in this first century of resettlement in Andalusia, controlled the financial activity in the Kingdom of Seville. 